Article

\title{
New Insights on the Estimation of the Anaerobic Biodegradability of Plant Material: Identifying Valuable Plants for Sustainable Energy Production
}

\author{
Claudia P. Pabón-Pereira ${ }^{1,2, *(\mathbb{C}, \text { H. V. M. Hamelers }}{ }^{2,3}$, Irene Matilla ${ }^{2}$ and Jules B. van Lier ${ }^{2,4}$ \\ 1 Faculty of Engineering and Sciences, Universidad Adolfo Ibañez, Diagonal Las Torres 2700, Peñalolen, C.P. \\ 7941169 Santiago de Chile, Chile \\ 2 Sub-department of Environmental Technology, Agrotechnology \& Food Sciences, Wageningen University, \\ 6708 PB Wageningen, The Netherlands; irene.mantilla@uv.es (H.V.M.H.); bert.hamelers@wetsus.nl (I.M.); \\ J.B.vanLier@TUDelft.nl (J.B.v.L.) \\ 3 Wetsus, European Centre of Excellence for Sustainable Water Technology, Oostergoweg 9, \\ 8911 MA Leeuwarden, The Netherlands \\ 4 Section Sanitary Engineering, Department of Water Management, Faculty of Civil Engineering and \\ Geosciences, Delft University of Technology, 2628 CN Delft, The Netherlands \\ * Correspondence: claudia.pabon@uai.cl; Tel.: +56-9-61403135
}

Received: 26 May 2020; Accepted: 1 July 2020; Published: 9 July 2020

check for updates

\begin{abstract}
Based on fifteen European plant species, a statistical model for the estimation of the anaerobic biodegradability of plant material was developed. We show that this new approach represents an accurate and cost-effective method to identify valuable energy plants for sustainable energy production. In particular, anaerobic biodegradability $\left(B_{0}\right)$ of lignocellulosic material was empirically found to be related to the amount of cellulose plus lignin, as analytically assessed by the van Soest method, i.e., the acid detergent fiber (ADF) value. Apart from being theoretically meaningful, the ADF-based empirical model requires the least effort compared to the other four proposed conceptual models proposed, as individual fractions of cellulose, hemicellulose, and lignin do not need to be assessed, which also enhances the predictive accuracy of the model's estimation. The model's results showed great predictability power, allowing us to identify interesting crops for sustainable crop rotations. Finally, the model was used to predict $B_{o}$ of 114 European plant samples that had been previously characterized by means of the van Soest method.
\end{abstract}

Keywords: anaerobic digestion; biodegradability; lignocellulosics; fiber degradation

\section{Introduction}

Closing material cycles through anaerobic digestion (AD) is an interesting alternative to provide valuable use to agricultural surplus products, agricultural residues, and energy-rich agro-industrial by-products, as well as to set aside land.

The use of $\mathrm{AD}$ for the production of biogas from crop material and residues is a renewable and carbon-neutral technologically viable option that also allows for the recirculation of nutrients and organic matter back to land, minimizing the need for external inputs and enhancing soil fertility [1-3]. AD of crops and agro-residues provides possibilities for storage and energy use on demand, contributes to sustainable energy self-sufficiency, and brings opportunities to farmers by means of rural income diversification [3,4]. Indeed, crops and agroresidues are interesting co-digestion materials supplementing waste materials of inferior energy quality, such as animal manure, allowing us to increase the energy output per unit reactor volume [5,6]. In addition, the AD potentials from fruit 
and vegetable waste has also been analyzed, considering its biogas yield [7] and its use as single AD component [8].

In Europe, incentives have been given for the use of crop material as (co) substrates for anaerobic reactors, with quantified available areas being 13.2 million Ha [6,9,10]. Mainly maize, sunflower, grasses, and some cereals have been preferred as crop substrates $[4,6]$. Challenges are found when digesting this type of lignocellulosic biomass due to its relatively low methane yield, potential process instability due to volatile fatty acids (VFA) accumulation, and production of low value end-products. Low methane yield can be caused by the recalcitrance of lignocellulosic biomass or retarded mass transfer in solid-state digestion systems [11]. Practical challenges are also the case when digesting crops in liquid digestion systems, include the difficulties in pumping due to the fibrous and low-density quality of this type of biomass, as well as the sizing and drying, both implying higher energy inputs [12]. Given the abovementioned, exploring different types of plant biomass, aiming for those better suited to overcome these challenges, is of interest.

Apart from the technological challenges, agricultural adaptability is also required for choosing for plant species for bioenergy production. Aspects such as the adaptability to grow under specific climatic conditions or degraded soils, or their suitability to be intercropped or grown within multipurpose situations using low inputs [13] are of particular importance, considering the ongoing discussions on competitive land use for food or energy purposes and environmental impacts of intensive agricultural systems. In a sustainable agroecosystem, the needs for food, energy, and nature conservation are addressed in an integrated way, whereas diversity is the key issue for enhancement of soil fertility, minimizing external inputs [14]. The use of legumes is an example of potentially very suitable multipurpose crops that produce food, allow soil fertility build-up, and improve gas yields [15].

The more than 250 thousand higher plants species in the world and the variations imposed by genotypes, cultivation methods, plant growth stage, and plant parts contribute to the diversity of materials potentially available for anaerobic digestion [16]. Knowledge on the anaerobic biodegradability of such potential substrates is needed in order to screen for the most suitable ones to be part of sustainable agroindustrial ecosystems [17]. Anaerobic biodegradability is defined as the susceptibility of a test substance to undergo a biologically mediated degradation without an external electron acceptor [18]. The biochemical methane potential (BMP) test is used to assess the ultimate anaerobic biodegradability $\left(B_{0}\right)$ from an organic substrate, under optimal laboratory conditions $[19,20]$. The BMP test is, however, time-consuming and yet not fully standardized [19,21], which sets limits to the possibilities for accurately screening materials and comparing results among different research works.

Studies have been performed to relate anaerobic biodegradability of lignocellulosic biomass to their physical-chemical composition. The characteristics reported to influence the degree of anaerobic degradation of lignocellulosic material include the content of lignin [22,23], hemicellulose, mannose (amongst hemicelluloses), and cellulose, as well as the cellulose crystallinity, the degree of association between lignin and carbohydrates [24], the wood-to-bark ratio [25], and the presence of toxic components [26]. Previous research has attempted to define mathematical equations for estimating anaerobic biodegradability based on lignocellulosic substrate composition. However, apart from energy crops silages [27] other substrates have been used, such as manure [28,29], wood [25,30], and solid waste material [26]; hence, differences in composition are expected, i.e., presence of toxic compounds and proportion of structural and non-structural components that could potentially influence the computed outcome. Furthermore, the different studies vary in their methods for treating the samples, assessing $\mathrm{BMP}$, and characterizing plant material, which might very well explain their different outcome.

In the present study, the BMP assessment of 15 selected European plant species, showing potential as part of sustainable agroecosystems, was performed by means of an optimized anaerobic protocol previously developed by the authors [20]. Further, empirical and conceptual models for estimating the biodegradability are examined, compared with previous research, and used to predict the anaerobic biodegradability of other European plant material. 


\section{Materials and Methods}

Plant material. The selected plant species were derived from an evaluation conducted as part of the EU Cropgen project, considering their attractive agronomic features, such as low energy input and nitrogen fixation potential, as well as their availability and multipurpose use for energy, food, industrial applications, and/or soil restauration. The test substrates consisted of 6 legumes, 2 perennial herbs, 2 pseudocereals, 2 cereals, 1 vegetable, 1 grass, and 1 oil crop. Most of the crop material used for this study was grown in glasshouse, i.e., legumes and pseudocereals, whereas few others were collected from the field in the UK, i.e., triticale. Homogeneous and representative samples were taken from full plants, considering the proportion of leaves, stems, and flowers. The fresh plant samples were freeze-dried, grinded, and sieved to pass through a $0.2 \mathrm{~mm}$ mesh, to avoid interference of particle size in biodegradability assays, as has been previously reported [20,31]. Resulting samples were fully characterized in terms of Total Solids (TS), Volatile Solids (VS), Chemical Oxygen Demand (COD), elemental composition (CHNO), fiber analysis, and starch (see Table 1). In addition, the proportion of soluble COD (sCOD) was assessed in order to distinguish between the plant material immediately solubilized and the remaining particulate fraction. Lignocellulosic composition was assessed by using the van Soest method [32]. The method is standardized and widely used in the field of animal sciences for predicting the energy of lactation based on lignocellulosic composition. Hence, potentially, a great number of data on composition of crop/feed material could become available for the estimation of the anaerobic digestion potential. In addition, the method has been used to relate BMP to substrate composition in previous research, hence allowing for results comparison. In Figure 1, the resulting VS characterization of the samples into its fibrous and non-fibrous components is presented.

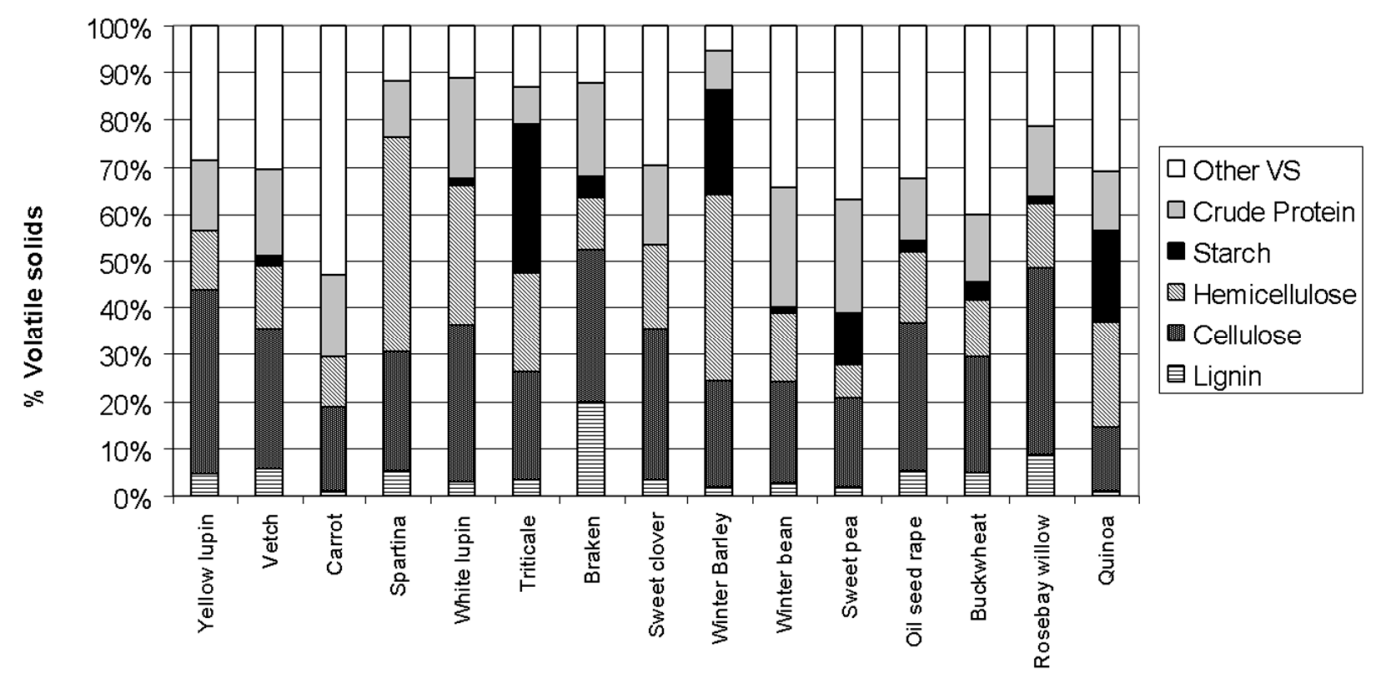

Figure 1. Volatile Solids composition of the 15 European plant samples evaluated.

Biochemical Methane Potential (BMP) test. The experimental setup for measuring the extent of degradation was an optimized Oxitop ${ }^{\circledR}($ WTW, Giessen, Germany) protocol previously developed [20] as a modified version of the method described by Owen et al. [33]. The batch test consisted of $500 \mathrm{~mL}$ serum bottles ( $600 \pm 10 \mathrm{~mL}$ working volume), with liquid contents occupying $150 \pm 10 \mathrm{~mL}$. The bottles were filled, starting with the nutrient medium solution and demineralized water, followed by the addition of the inoculum and substrate. A phosphate buffer solution was used at a $20 \mathrm{mM}$ concentration. Thereafter, bottles were flushed with $\mathrm{N}_{2}$ gas for $1 \mathrm{~min}$ and tightly sealed. The bottles were incubated at $35( \pm 0.5){ }^{\circ} \mathrm{C}$ and continuously shaken at $120 \mathrm{rpm}$ for two weeks; afterward, they were shaken three times per week, manually. 
Table 1. Plant samples' characteristics.

\begin{tabular}{|c|c|c|c|c|c|c|c|c|c|c|c|}
\hline \multirow{2}{*}{ Common Name } & \multirow{2}{*}{ Scientific Name } & \multirow{2}{*}{ Crop Type } & \multirow{2}{*}{ TS $\left(\mathrm{gTS} \mathrm{g}^{-1}\right)$} & \multirow{2}{*}{ VS (\%TS) } & \multirow{2}{*}{$\operatorname{COD}\left(\mathrm{gO}_{2} \mathrm{gVS}^{-1}\right)$} & TF & L & $\mathrm{C}$ & $\mathbf{H}$ & Starch & Protein \\
\hline & & & & & & \multicolumn{6}{|c|}{ (g.gVS-1) } \\
\hline Yellow lupin & Lupinu luteus & Legume & 0.15 & $91 \%$ & 1.54 & 0.58 & 0.04 & 0.41 & 0.13 & 0.00 & 0.15 \\
\hline Vetch & Vicia sativa & Legume & 0.24 & $93 \%$ & 1.47 & 0.51 & 0.06 & 0.32 & 0.13 & 0.03 & 0.18 \\
\hline Spartina & Spartina anglica & Wild grass & 0.32 & $89 \%$ & 1.42 & 0.77 & 0.05 & 0.26 & 0.46 & 0.00 & 0.12 \\
\hline White lupin & Lupinus albus & Legume & 0.14 & $93 \%$ & 1.46 & 0.65 & 0.03 & 0.32 & 0.30 & 0.01 & 0.21 \\
\hline Triticale & Triticum secale & Cereal & 0.70 & $97 \%$ & 1.43 & 0.47 & 0.04 & 0.22 & 0.21 & 0.32 & 0.08 \\
\hline Bracken & Pteridium aquilinum & Fern-perennial & 0.16 & $94 \%$ & 1.51 & 0.63 & 0.20 & 0.32 & 0.11 & 0.05 & 0.20 \\
\hline Sweet clover & Melilota officinalis & Legume & 0.33 & $94 \%$ & 1.58 & 0.53 & 0.03 & 0.32 & 0.18 & 0.00 & 0.17 \\
\hline Winter bean & Vicia faba & Legume & 0.15 & $92 \%$ & 1.52 & 0.42 & 0.03 & 0.24 & 0.15 & 0.01 & 0.26 \\
\hline Sweet pea & Pisum sativum & Legume & 0.15 & $90 \%$ & 1.53 & 0.29 & 0.02 & 0.20 & 0.07 & 0.11 & 0.24 \\
\hline Oilseed rape & Brassica napus & Oil crop & 0.26 & $93 \%$ & 1.62 & 0.54 & 0.05 & 0.33 & 0.15 & 0.02 & 0.13 \\
\hline Buckwheat & Fagopyrum esculentum & Pseudo cereal & 0.17 & $90 \%$ & 1.45 & 0.44 & 0.05 & 0.26 & 0.12 & 0.04 & 0.14 \\
\hline Rosebay willow & Chamaenerion angustifolium & Herb-perennial & 0.38 & $94 \%$ & 1.53 & 0.76 & 0.09 & 0.40 & 0.14 & 0.02 & 0.15 \\
\hline Quinoa & Chenopodium quinoa & Pseudo cereal & 0.22 & $86 \%$ & 1.35 & 0.27 & 0.01 & 0.13 & 0.23 & 0.19 & 0.13 \\
\hline
\end{tabular}

Notes: VS, Volatile Solids; TS, Total Solids; COD, Chemical Oxygen Demand; TF, total fiber; L, lignin; C, cellulose; H, hemicellulose. 
The test was carried out in triplicate and was followed by means of daily sampling for liquid and gas samples, during the first two weeks, following $\mathrm{pH}, \mathrm{VFA}$, and $\mathrm{CH}_{4}$ contents, in order to ensure no inhibitory VFA accumulation was taking place. The end of the test was assured by controlling the change in pressure in the bottles and verifying less than $1 \%$ brut gas production took place during at least 3 days [19]. All samples were analyzed in two experimental tests, using the same inoculum with a 40-day time difference. One of the plant species analyzed, quinoa, was used as control sample for the subsequent experimental test (internal standard).

Inoculums. A sludge mixture consisting of active suspended digested primary sludge and anaerobic granular sludge was added. The digested primary sludge originated from a wastewater treatment plant in the vicinity of Ede, The Netherlands (NL), working at mesophilic temperatures, having $0.023 \mathrm{gVS}^{-1}$ and $1.70 \mathrm{~g} \mathrm{COD}^{-1}$. The granular sludge originated from a mesophilic upflow anaerobic sludge blanket (UASB) treating alcohol distillery effluents; its analyses showed $0.058 \mathrm{gVS}^{-1}$ and $0.82 \mathrm{gCOD}^{-1}$. SMA tests in acetate and glucose, were performed for both inocula; results were $0.23 \mathrm{gVS} \mathrm{g} 1^{-1} \mathrm{~d}^{-1}, 39.45 \pm 8.0 \mathrm{mgCOD} \mathrm{gVS} 1^{-1} \mathrm{~d}^{-1}$ for the digested sludge, and $1.78 \mathrm{gCOD} \mathrm{gVS} \mathrm{g}^{-1} \mathrm{~d}^{-1}$, $89.02 \pm 4.9 \mathrm{mgCOD} \mathrm{gVS} 1^{-1} \mathrm{~d}^{-1}$ for the granular sludge.

Both inoculums were added, keeping a substrate-to-inoculum ratio (S/I ratio) equal to 0.5 (VS basis), in order to guarantee adequate presence of hydrolytic and methanogenic microbial populations [19,20].

Analytical methods. For the characterization of the substrates and sludges, freeze-drying was performed in liquid nitrogen, in a GRI 20-85 MP freeze drier (GRInstruments, Wijk bij Duurstede, Uthrecht, The Netherlands) equipped with two condensers. Comminution was performed in a Retsch BV grinder (Retch BV, Haan, Dusseldorf, Germany). TS, VS, and COD (macro COD) were performed according to standard methods [34]. Total COD was measured by oxidizing a sample of suspended plant material, i.e., 20 g plant per 1 demineralized water, using potassium dichromate under acidic conditions and AgI as catalyst. Titrimetric analysis with Mohr's salt allowed us to determine the excessive amount of dichromate added, thereby elucidating the amount of oxygen used for oxidating the organic matter in the sample. Then, sCOD was determined by means of centrifuging samples for ten minutes at $10.000 \mathrm{rpm}$ in a Microlite Therme IEC Boomlab centrifuge (Thermo Fisher Scientific, Meppel, The Netherlands). The supernatant was then filtered at $0.45 \mathrm{~mm}$ pore size, and the obtained liquid was analyzed, using Dr. Lange kits (Hach, Dusseldorf, Germany), measured in a Dr. Lange Xion 500 model LPG-385 photospectrometer (Hach, Dusseldorf, Germany). The particulate COD (pCOD) was obtained by means of subtracting the sCOD fraction from the Total COD.

The elemental analysis (EA) of the freeze-dried grinded materials was performed in a Thermoquest EA 1110 CHNS-O (CE Instruments, Milan, Italy) equipped with a prepacked quartz reactor column. From the EA, COD was also calculated by applying the Buswell's formula [35]. Crude protein content was calculated by multiplying the nitrogen content assessed by elemental analysis by 6.25 [36]. As mentioned, fiber analysis was performed according to van Soest [32], using the freeze-dried grinded samples. Using the crucible system, $1 \mathrm{~g}$ of dried sample was analyzed, using sodium lauryl sulfate, sulfuric acid, and alfa-amylase as reagents, and the sequential system was selected to determine neutral detergent fiber (NDF), acid detergent lignin (ADL), and neutral detergent acid detergent fibers (NDADFs). All analyses were performed in triplicate or duplicate.

Gas composition was followed with a Hewlett Packard 5890A gas chromatograph; the temperatures of the oven, the injection port, and the detector temperature were 45,110 , and $99{ }^{\circ} \mathrm{C}$, respectively. A Molesieve column of $0.53 \mathrm{~mm} \times 15 \mu \mathrm{m}$ was used to measure oxygen, nitrogen, and methane, and a paraplot $0.53 \mathrm{~mm} \times 20 \mu \mathrm{m}$ column was used to assess carbon dioxide.

Calculations. The BMP, expressed as liters of methane at standard temperature and pressure $\left(273^{\circ} \mathrm{K}\right.$ and $\left.10^{5} \mathrm{~Pa}\right)$ per amount of substrate Volatile Solids added $\left(1 \mathrm{CH}_{4}-\mathrm{STP} \cdot \mathrm{gVS}{ }^{-1}\right)$ was calculated from the methane production of the sample bottle at the end of the test and corrected by the methane production of the blank bottle at the end of the test (Equation (1)). The moles of methane produced were calculated by applying the ideal gas equation to the total pressure increase and multiplying the 
biogas moles by the percentage of methane in the headspace. Average and standard deviation from the triplicates were accounted.

$$
B M P=\frac{\left[\frac{\left(P_{s}+P_{a t m}\right) \times V_{s}}{R \times T}\right] \times \frac{\% C H_{4 s}}{100}-\left[\frac{\left(P_{b l}+P_{a t m}\right) \times V_{s}}{R \times T}\right] \times \frac{\% C H_{4 b l}}{100}}{S_{o}} \times 22.4
$$

where $P_{S}$ is the final pressure in the sample bottle (atm), $P_{a t m}$ is the atmospheric pressure $(\mathrm{atm}), P_{b l}$ is the pressure in the blank bottle (atm), $V_{S}$ is the headspace volume of the test bottle (l), $V_{b l}$ is the headspace volume of the blank bottle (l), $T$ is the temperature $\left(308.16^{\circ} \mathrm{K}\right), R$ is the universal gas constant $\left(0.082061 \mathrm{~atm} \mathrm{~mol}{ }^{-1}{ }^{\circ} \mathrm{K}^{-1}\right), \% \mathrm{CH}_{4 s}$ is the per is the percentage methane in the test bottle, $\% \mathrm{CH}_{4 b l}$ is the percentage methane in the blank bottle, 22.4 is a conversion factor ( $1 \mathrm{STP} \mathrm{mol}^{-1}$ ), and $S_{o}$ is the amount of substrate added (gVS).

The anaerobic biodegradability achieved under our defined test conditions $\left(B_{0}\right)$ is defined as the maximum percentage $C O D$ added converted to methane, and it is calculated as the ratio between the net accumulated methane as COD divided by the total COD amount added in the bottle [37], as shown in Equation (2).

$$
B_{0}=\frac{C H_{4, t=\max }}{S_{0}} \times \frac{2.86}{C O D_{s}} \times 100
$$

where $\mathrm{CH}_{4, t=\max }$, is the net amount of methane produced at final digestion time (l), $S_{o}$ is the amount of substrate added (gVS), 2.86 corresponds to the COD equivalence of $1 \mathrm{~L}$ methane at standard temperature and pressure $\left(\mathrm{gCOD}^{-1}\right)$, and $C O D_{s}$ is the $C O D$ of the sample $\left(\mathrm{gCOD} \mathrm{gVS}^{-1}\right)$.

The maximum biodegradability of the particulate material $B_{p}$ is calculated by using Equation (3).

$$
B_{p}=\left(\frac{C O D_{\text {methane, } t=\infty}+C O D_{s, t=\infty}-C O D_{s, t}=0}{C O D_{\text {in }}-C O D_{s, t}=0}\right)
$$

where $C O D_{\text {methane, } t=\text { max }}$ is the $C O D$ equivalent concentration of methane produced at final digestion time $\left(\mathrm{gCOD} .1^{-1}\right), C O D_{s, t=\max }$ is the soluble $C O D$ at final digestion time $\left(\mathrm{gCOD} .1^{-1}\right), C O D_{s, t=0}$ is the concentration soluble $C O D$ at time $t=0\left(\mathrm{gCOD} \cdot \mathrm{l}^{-1}\right)$, and $C O D_{\text {in }}$ is the total initial $C O D$ concentration in the bottle (gCOD. $\left.1^{-1}\right)$.

Similarly, the maximum biodegradability of the soluble material $B_{S}$ is calculated by using Equation (4).

$$
B_{s}=\left(\frac{C O D_{s, t=0}+C O D_{\text {methane }, t=\text { max }}-C O D_{s, t}=\text { max }}{C O D_{s, t}=0}\right)
$$

Statistical analysis. Statistical data analysis was performed for validating the models, using anaerobic biodegradability, $B_{0}$, as a dependent variable. First, a regression was used to see the significance of each explanatory variable, using the $p$-value of a t-statistic. Second, theoretical models were tested by using F-statistics and $\mathrm{R}^{2}$ to explore the closeness of their prediction; the Residual Sum of Squares (RSS) was used to account for the amount of variance that is not explained by a certain model.

\section{Results}

Anaerobic biodegradation of the assessed plant material. Biogas production of prepared samples rapidly proceeded. The maximum biogas amount was reached, in most cases, after 25 days of digestion, whereas less than $1 \%$ net gas production was produced in the last 8-10 days of the experiment (see Figure 2). Reproducibility of the test was excellent, and the average difference in biogas production amongst duplicates was 3\%, fluctuating between $1 \%$ and $5 \%$. Measured maximum net biogas production in all plant species was between 0.22 and $0.56 \mathrm{gVS}^{-1}$, with most of the species being in the range between 0.34 and $0.441 . \mathrm{gVS}^{-1}$. 


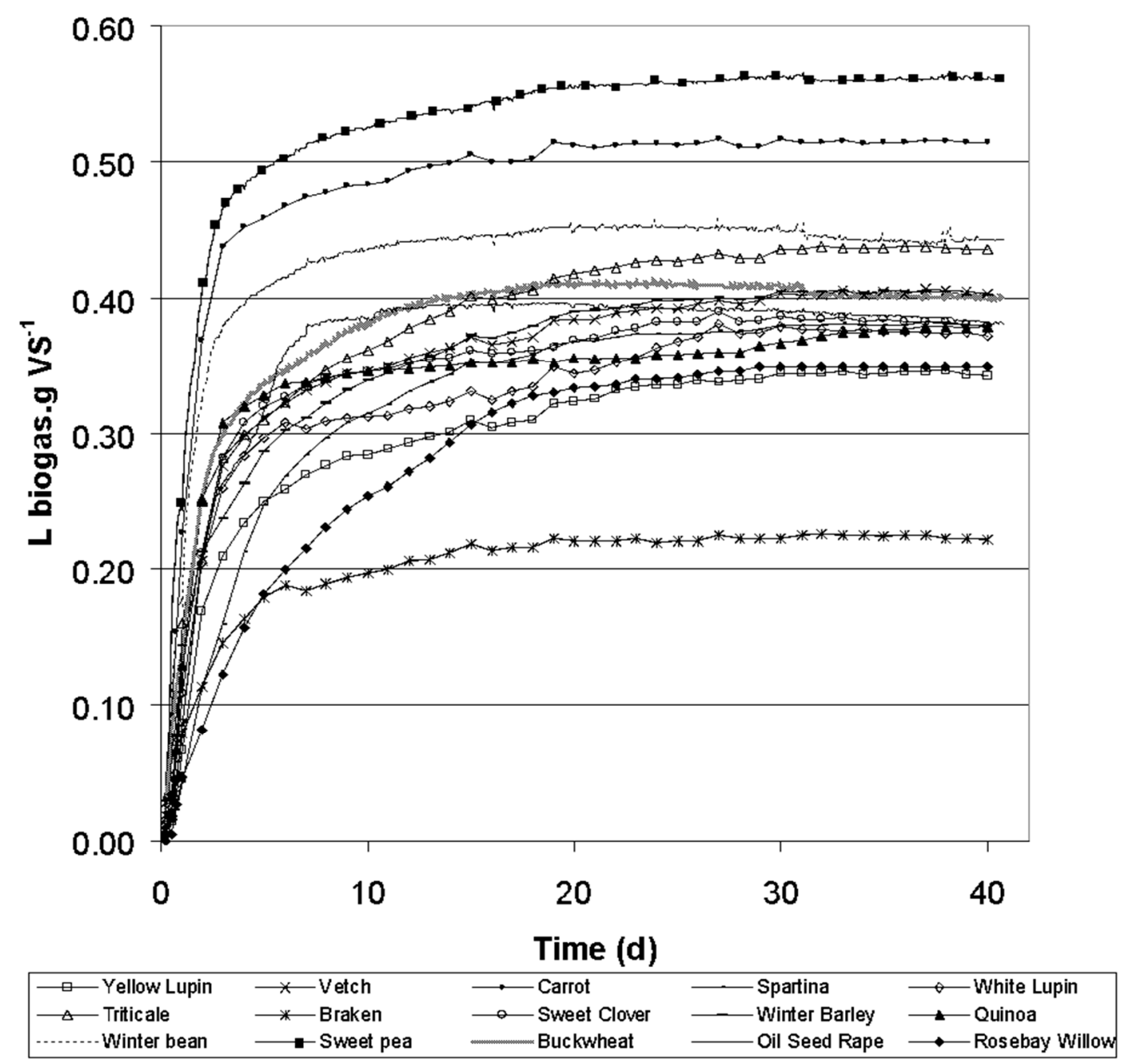

Figure 2. Net biogas accumulation during BMP assessment of fifteen plant samples, applying the optimized BMP protocol.

Biogas composition showed an average $65 \%$ of methane in the final gas, varying in the range $61-71 \%$. The methane concentration increased in time during the first four days of the study varied between $56 \%$ and $65 \%$, thereafter remaining stable.

Table 2 presents the BMP and $B_{0}$ assessed for the tested materials. The BMP of the 15 plant samples assessed ranged from 0.18 to 0.37 , being on average $0.29 \mathrm{lCH}_{4} \cdot \mathrm{gVS}^{-1}$. Two leguminous species, sweet pea and winter bean, showed the highest BMP values, i.e., above $0.351 \mathrm{CH}_{4} \cdot \mathrm{gVS}^{-1}$, followed by carrot and the (pseudo)cereals buckwheat and quinoa. The two samples of perennial wild species, bracken and rosebay willow, showed the lowest biodegradability, i.e., below $37 \%$.

Biodegradability was also assessed in relation to the form of the organic material in the samples, i.e., particulate or soluble. The proportion of particulate $C O D$ in relation to the total $C O D$ was, on average, $77 \%$, varying from $50 \%$ to $88 \%$. The achieved average maximum degradation of particulate and soluble COD was $46 \%$ and $94 \%$, respectively. Whereas anaerobic degradation of particulate COD showed a variation in the range of $22-62 \%$, the soluble COD biodegradability varied in a narrower range (86-100\%) (see Table 2). 
Table 2. BMP and biodegradability, as assessed from batch digestion of 15 European plant species.

\begin{tabular}{|c|c|c|c|c|c|}
\hline Specie & $\begin{array}{c}\text { BMP } \\
\left(1 \mathrm{CH}_{4} \mathrm{gVS}^{-1}\right)\end{array}$ & $\begin{array}{c}\text { BMP } \\
\left(\mathrm{lCH}_{4} \mathrm{gCOD}^{-1}\right)\end{array}$ & $\begin{array}{c}B_{o} \\
(\% \text { COD })\end{array}$ & $\begin{array}{c}B_{p} \\
(\% \mathrm{pCOD})\end{array}$ & $\begin{array}{c}B_{s} \\
(\% s C O D)\end{array}$ \\
\hline Yellow lupin & $0.26 \pm 0.01$ & $0.16 \pm 0.01$ & $47 \%$ & 36 & 92 \\
\hline Vetch & $0.29 \pm 0.02$ & $0.20 \pm 0.01$ & $56 \%$ & 43 & 99 \\
\hline Carrot & $0.31 \pm 0.01$ & $0.23 \pm 0.01$ & $66 \%$ & 31 & 100 \\
\hline Spartina & $0.29 \pm 0.01$ & $0.21 \pm 0.01$ & $59 \%$ & 52 & 97 \\
\hline White lupin & $0.26 \pm 0.01$ & $0.18 \pm 0.01$ & $52 \%$ & 35 & 100 \\
\hline Triticale & $0.29 \pm 0.00$ & $0.20 \pm 0.00$ & $57 \%$ & 52 & 86 \\
\hline Bracken & $0.18 \pm 0.01$ & $0.12 \pm 0.01$ & $34 \%$ & 22 & 92 \\
\hline Sweet clover & $0.29 \pm 0.01$ & $0.18 \pm 0.01$ & $53 \%$ & 42 & 88 \\
\hline Winter barley & $0.30 \pm 0.01$ & $0.21 \pm 0.01$ & $60 \%$ & 51 & 93 \\
\hline Winter bean & $0.35 \pm 0.02$ & $0.23 \pm 0.02$ & $66 \%$ & 55 & 89 \\
\hline Sweet pea & $0.37 \pm 0.03$ & $0.24 \pm 0.02$ & $70 \%$ & 61 & 93 \\
\hline Oilseed rape & $0.29 \pm 0.02$ & $0.18 \pm 0.01$ & $51 \%$ & 59 & 90 \\
\hline Buckwheat & $0.32 \pm 0.02$ & $0.22 \pm 0.01$ & $63 \%$ & 54 & 98 \\
\hline Rosebay willow & $0.20 \pm 0.01$ & $0.13 \pm 0.01$ & $37 \%$ & - & - \\
\hline Quinoa & $0.33 \pm 0.02$ & $0.24 \pm 0.01$ & $70 \%$ & - & - \\
\hline
\end{tabular}

$B_{0}$ : proportion of Total COD converted into methane by the end of the digestion time. $B_{p}$ : proportion of the particulate $C O D$ that was methanized by the end of the digestion time. $B_{s}$ : proportion of the soluble $C O D$ that was methanized by the end of the digestion time.

$B_{o}$ and plant composition. The amounts of specific structural fiber components varied between species (see Table 1 and Figure 1). Samples were mainly composed of holocellulose, i.e., cellulose and hemicellulose, in the range $0.27-0.72 \mathrm{~g} \mathrm{gVS}^{-1}$, whereas the assessed fraction of lignin was found to be much smaller, viz. in the range $0.01-0.20 \mathrm{~g} \mathrm{gVS}^{-1}$. Crude protein fractions were also found to be important, ranging between 0.08 and $0.26 \mathrm{~g} \mathrm{gVS}^{-1}$, whereas starch fractions were generally low and only important in samples of (pseudo) cereals, namely triticale, winter barley, and quinoa. The previous features in composition can be attributed to the crop selection, as most of the species studied were legumes, which are crops known to have significant portions of proteins, low starch content, and a great variety of growth forms, i.e., from small herbaceous species to large woody trees.

The individual fiber fractions, as determined by the van Soest method, and the fractions of crude protein and starch were assessed for their relation to $B_{0}$ of the tested plant samples. Single- and multiple-variable equations were obtained by means of linear regression and tested by F-statistics, using the statistical program Genstat 9th edition (Table 3). The best fit was obtained by correlating the ADF content of the plant samples with the assessed BMP value, yielding a correlation coefficient $\left(R^{2}=0.86\right)$ and a high level of significance, $<0.0001$. The linear model based on the individual components lignin and cellulose had a similar correlation coefficient with both cellulose and lignin, showing a good level of significance, i.e., $\leq 0.005$. The total fiber content was the poorest predictor of $B_{0}\left(R^{2}=0.37\right)$. Moreover, lignin content alone showed to be a poor indicator for overall maximum anaerobic biodegradation $\left(\mathrm{R}^{2}=0.61\right)$, although the statistical relations tested show better correlation when this fraction is included in the equations. The cellulose content showed to be significantly related to the sample biodegradability in most of the studied models. Increasing the number of variables involved in the model, including starch and/or crude protein content, only slightly affected the correlation coefficient, whereas the level of significance of these other predictor variables remained low. 
Table 3. Number of parameters ( $p)$, coefficient of determination $\left(R^{2}\right)$, and significance ( $p$-values) for the estimation of biodegradability from different plant components.

\begin{tabular}{|c|c|c|c|c|c|c|c|c|c|}
\hline \multirow[t]{2}{*}{ Model Variables } & \multirow[t]{2}{*}{$p$} & \multirow[t]{2}{*}{$\mathbf{R}^{2}$} & \multicolumn{7}{|c|}{$\begin{array}{c}\text { Predictor Variables } \\
p \text {-Values }\end{array}$} \\
\hline & & & NDF & ADF & $\mathrm{C}$ & $\mathbf{H}$ & $\mathbf{L}$ & $\mathrm{CP}$ & St \\
\hline $\mathrm{ADF}$ & 2 & 0.86 & - & 0.000 & - & - & - & - & - \\
\hline C, L & 3 & 0.87 & - & - & 0.000 & - & 0.001 & - & - \\
\hline $\mathrm{ADL}=\mathrm{L}$ & 2 & 0.61 & - & - & - & - & 0.000 & - & - \\
\hline NDF & 2 & 0.37 & 0.010 & - & - & - & - & - & - \\
\hline C & 2 & 0.65 & - & - & 0.000 & - & - & - & - \\
\hline $\mathrm{C}, \mathrm{H}$ & 3 & 0.63 & - & - & 0.000 & 0.953 & - & - & - \\
\hline $\mathrm{C}, \mathrm{L}, \mathrm{St}$ & 4 & 0.88 & - & - & 0.000 & - & 0.000 & - & 0.138 \\
\hline $\mathrm{C}, \mathrm{L}, \mathrm{CP}$ & 4 & 0.88 & - & - & 0.000 & & 0.000 & 0.132 & - \\
\hline $\mathrm{C}, \mathrm{H}, \mathrm{L}$ & 4 & 0.87 & - & - & 0.000 & 0.385 & 0.001 & - & - \\
\hline
\end{tabular}

Notes: NDF, neutral detergent fiber; ADF, acid detergent fiber; ADL, acid detergent lignin; C, cellulose; $\mathrm{H}$, hemicellulose; L, lignin; $\mathrm{CP}$, crude protein; St, starch.

Figure 3 presents the test for linearity between fiber components and substrate biodegradability. Although it can be observed that bracken, the sample with the highest lignin content, exerts an important leverage effect in the equation relating lignin with biodegradability, when omitting this sample, the strength of the correlation does not change $\left(R^{2}=0.60\right)$.

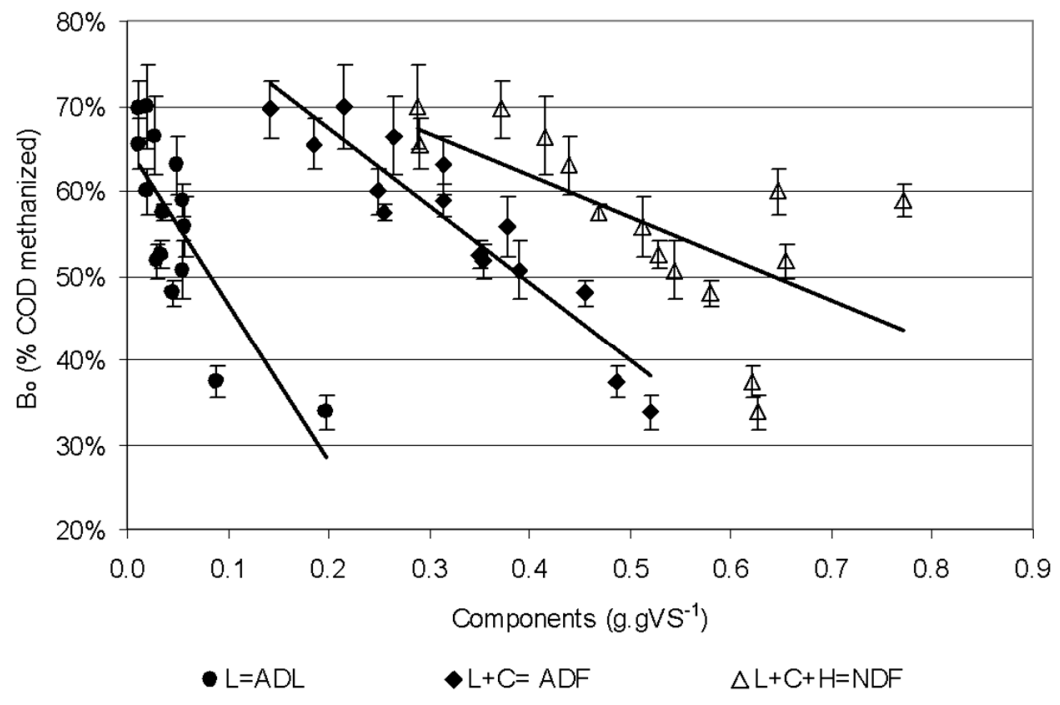

Figure 3. Percentage maximum methanized $C O D\left(B_{0}\right)$ in dependence of fiber components.

Our results show the suitability of most selected crop species to undergo anaerobic degradation. Furthermore, a strong correlation between fiber components and biodegradability of plant material of different origin was determined. The meaning of the developed model and of the BMP values is examined in more detail and set in a broader context.

Interactions among plant cell-wall components and $\boldsymbol{B}_{\boldsymbol{o}}$. Often, linear regression of single or multiple parameters is used to describe the correlation between data points, without having the direct causal relation elucidated. However, the value of a specific model has to be judged against available knowledge, which is, in our case, on the anaerobic degradation properties of lignocellulosic materials.

Plant material is composed of intra-cellular soluble material and different types of structural tissues, namely lignin, cellulose, and hemicellulose. Cell contents contained within the boundaries of the cell wall include sugars and storage or reserve carbohydrates, such as starch, fructosans, and galactans, as well as proteins (e.g., enzymes) and lipids. They vary a lot in proportion amongst 
different species and are highly biodegradable. Structural tissues, in turn, can make up to $90 \%$ or more of the composition of wood [30], whereas lower and more variable proportions are present in herbaceous materials. Cellulose is the main constituent of the primary, most external, cell wall of green plants, whereas variable amounts of lignin and hemicellulose, along with cellulose, are present in the secondary wall. Lignin is a complex compound non-uniform in chemical and physical composition [38]. The compound is mainly refractory under anaerobic conditions, although there is evidence that shows its (partial)degradation in anaerobic environments $[39,40]$. The mechanism through which lignin affects holocellulose decomposition could either be through blocking the access of microorganisms to the more degradable areas [39], or through inhibitory effects coming from lignin compounds or its hydrolysates [41-43]. A study carried out with excavated refuse samples suggests that bioavailability of degradable carbohydrates, rather than toxicity, limited methane production [44].

Lignin was proposed as the single indicator for estimating the anaerobic biodegradability of lignocellulosic material [22,45]. However, our findings point to the combination of lignin and cellulose as being the explanation, in agreement with Tong et al. [24] and Chynoweth et al. [46], reporting the poor value of lignin as a sole predictor.

Apart from its recalcitrance, the impact of lignin on anaerobic biodegradation is mainly associated with its role in lignocellulose complexes. The encrustation of cellulose by lignin within the lignocellulosic matrix has been reported to hamper the extent and rate of degradation of the more degradable holocellulose components [47,48].

Our results show that the sum lignin plus cellulose, as assessed by the van Soest method, correlates better with the anaerobic biodegradability compared to a single component correlation. Hence, these results support the argument that the lignin-cellulose matrix, and thus lignin encrustation, rather than lignin alone, determines the digestibility of lignocellulosic biomass. Similarly, the hydrolysis assessments performed point to the lignocellulosic matrix as being of relevance for the prediction of the degradation rate [49].

In the past, a link between the sum lignin and cellulose and biodegradability of organic wastes was indicated [50]; however, no statistical analysis was reported. The regression equation obtained under our reported test condition implies the relation could be described by L is Lignin $\left(\mathrm{gVS} \mathrm{g}^{-1}\right)$ and $\mathrm{C}$ is Cellulose $\left(\mathrm{gVS} \mathrm{g}^{-1}\right)$, as shown in Equation (5).

$$
B_{0}=0.86-0.92(L+C) \text { with } L \neq 0 \text { and } C \neq 0
$$

Equation (5) proposes a logic approach to biodegradability as follows. It establishes an absolute maximum biodegradability of 0.86 , which is in close relation to the calculated conversion efficiencies reported by Reference [26] and is consistent with expected COD used for bacterial growth. It also proposes a decreased biodegradability in relation to the sum lignin plus cellulose. Since the ADF value is expressed in $\mathrm{g} \mathrm{gVS}^{-1}$, a conversion factor of $1.2 \mathrm{gCOD} \mathrm{gVS}^{-1}$ corresponding to average COD content of lignin and cellulose $[18,29,44]$ is implicit in the term 0.92 . Hence, it is suggested that about $77 \%$, i.e., $0.92 / 1.2$, of the sum lignin plus cellulose is not degraded.

Statistically, such interaction between lignin and cellulose can be tested by including an extra term in the equation, accounting for the product terms of the two variables. Equation (6) shows the tested equation, which has a similar coefficient of determination $\left(R^{2}=0.88\right)$ and good significance $\left(\mathrm{F}_{\text {test }}<0.001\right)$. The interaction amongst the variables is proven by the fact that the extra parameter is different from $0(=1.87)$, implying that the effect of the individual variables is dependent on the value of the other. Given that the individual significance of the extra term remains low, i.e., $t=0.137>0.005$, Equation (5) seems to be more accurate than Equation (6).

$$
B_{0}=0.81-0.69(L+C)-1.87(L \times C)
$$

Estimation of $\boldsymbol{B}_{\boldsymbol{o}}$ based on individual fiber components. Equation (5) was further compared with conceptual models where the individual fractions of plant components are given different 
biodegradability values, considering their properties. The equations depart from an overall equation assigning different biodegradability properties to cellulose $\left(C_{i}\right)$, hemicellulose $\left(H_{i}\right)$, and the cell solubles $\left(C S_{i}\right)$, as shown in Equation (7).

$$
B_{o i}=\left(B_{o C} \times C_{i} \times C_{a v}\right)+\left(B_{o H} \times H_{i} \times H_{a v}\right)+\left(B_{o C S} \times C S_{i}\right)-X_{b}
$$

In Equation (7), the subscript $i$ in the equation refers to each of the plant materials tested. The method of minimization of sum of squares was used to estimate the individual biodegradability of cellulose $\left(B_{O C}\right)$, hemicellulose $\left(B_{O H}\right)$, and cell solubles $\left(B_{O C S}\right)$ and to estimate the average amount of substrate converted to microbial biomass $\left(X_{b}\right)$. Note that $B_{o i}+X_{b}$ accounts for the total degraded COD.

Different mathematical relations for the definition of the fractions of bio-available cellulose $\left(C_{a v}\right)$ and hemicellulose $\left(H_{a v}\right)$ were tested. Table 4 presents Models I, II, and IV and their statistical performance.

Table 4. Equations, number of parameters (p), coefficient of determination $\left(\mathrm{R}^{2}\right)$, and significance (RSS) for the estimation of anaerobic biodegradability based on a deterministic approach.

\begin{tabular}{clcccc}
\hline & \multicolumn{1}{c}{ Model } & Assumption Tested & $\mathbf{R}^{2}$ & RSS & $\mathbf{F}_{\mathbf{p r}}$ \\
\hline I & $\hat{B}_{o}=\left(0.22 \times C_{i} \times C_{a v}\right)+\left(1.01 \times\left(N D S_{i}+H_{i}\right)\right)-0.17$ & $C_{a v}=\frac{C-L}{C}$ & 86 & 0.006 & $<0.001$ \\
II & $\hat{B}_{o}=\left(0.58 \times C_{i} \times C_{a v}\right)+\left(0.85 \times H_{i} \times H_{a v}\right)\left(1.14 \times N D S_{i}\right)-$ & $C_{a v}=\frac{C-L}{C}$ & 81 & 0.016 & $<0.001$ \\
& 0.25 & $H_{a v}=\frac{H-L}{H}$ & & & \\
III & $\hat{B}_{o}=\left(0.74 \times\left(C_{i}+H_{i}\right) \times C H_{a v}\right)+\left(1.04 \times N D S_{i}\right)-0.25$ & $C H_{a v}=\frac{C+H-L}{C+H}$ & 73 & 0.011 & $<0.001$ \\
IV & $\hat{B}_{0}=\left(0.86 \times\left(C_{i}+H_{i}\right) \times C H_{a v}\right)+\left(1.07 \times N D S_{i}\right)-0.28$ & $C H_{a v}=1-\frac{L^{\frac{2}{3}}}{N D F^{\frac{2}{3}}}$ & 75 & 0.011 & $<0.001$ \\
\hline
\end{tabular}

Notes: $C$, cellulose; $H$, hemicellulose; $L$, lignin; av, available; $N D S$, neutral detergent solubles.

Models I and II are first approximations into an individual quantitative relation between the biodegradability of the fractions of cellulose and lignin, and hemicellulose and lignin, respectively. Model III is similar but considers both cellulose and hemicellulose to act as one entity. In Model IV, the relation between lignin and holocellulose availability $\left(\mathrm{CH}_{a v}\right)$ is considered to be surface-related, as previously proposed by Conrad et al. [51], when estimating maximum rumen digestibility of animal feeds. Such surface relation considers that lignin and the rest of cell walls are located close to the surface and that the surface of any geometric object can be calculated as the square of the mean linear dimension of the two-third power of its mass (See Table 4).

The four conceptual models tested were found to be statistically sound, if judging from the $\mathrm{R}^{2}$ and $F_{\text {test }}$ value. In addition, all models give reasonable values of biodegradability of non-cell-wall components $\left(B_{o C S}\right)$ and microbial biomass $\left(X_{b}\right) . B_{o C S}$ is in the range of $1.01-1.14$, which means a $72-81 \%$ biodegradability, considering an average COD content of cell solubles of $1.3-1.5 \mathrm{gCOD} \mathrm{gVS}^{-1}$. On the other hand, $11-19 \%$ of the added substrate is expected to end as bacterial cell yield $\left(X_{b}\right)$, if assuming an average anaerobic bacterial composition of $\mathrm{C}_{5} \mathrm{H}_{7} \mathrm{O}_{2} \mathrm{~N}$, giving a COD content of $1.42 \mathrm{gCOD} \mathrm{gVS}^{-1}$. With regard to the biodegradability figures estimated for cellulose and hemicellulose, Model IV is closer to the theoretically expected full anaerobic biodegradability of cellulose and hemicellulose in their pure form [30,52].

All models developed, including the empirical one (Equation (5)), were used to predict anaerobic biodegradability based on the chemical composition of the various assessed crops (Figure 4). 


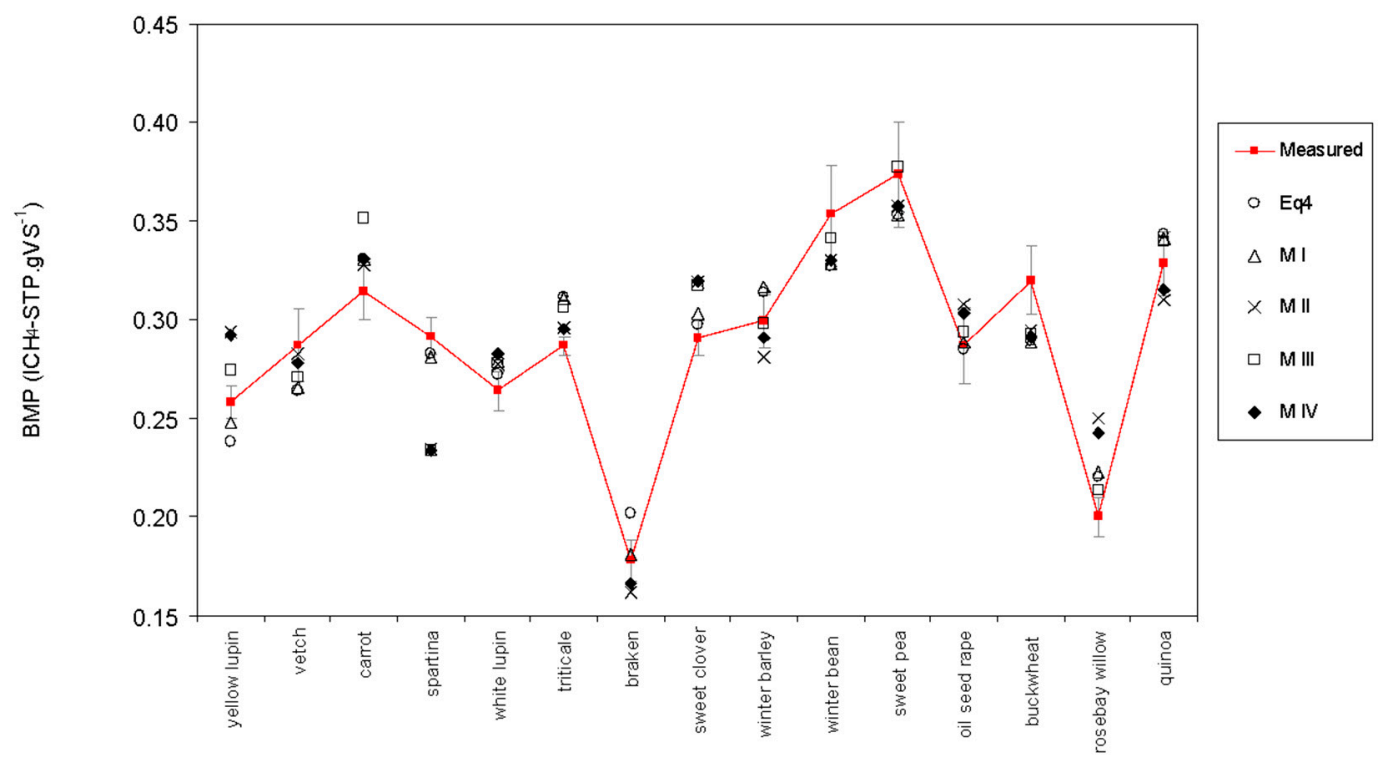

Figure 4. BMP estimation, using different model equations. ${ }^{*}$ Equations are described in Table 4.

It can be observed that the predictions of the empirical equation (Equation (5)) and Model I, relating the fraction lignin to cellulose, are in close agreement. In addition, all models would allow us to screen for suitable plant material for anaerobic digestion in a similar way as the experiment performed. However, equations, including hemicellulose, and Models II, III, and IV, particularly fail to predict $B_{o}$ of one of the samples, i.e., spartina. Spartina is the specie with the highest hemicellulose content and the only grass specie included in this study. Grasses seem to have significant amounts of acid soluble lignin, whereas the hemicellulose content in the primary cell wall is higher [53]. When looking closer into the relationship between total fiber and biodegradability (Figures 1 and 3; Tables 1 and 2), it is clear that the three data points showing the highest content of hemicellulose, i.e., spartina, white lupin, and winter barley, showed higher $B_{0}$ than other samples having similar total fiber content but higher relative cellulose content, such as bracken and rosebay willow. When the model is tested while omitting the three species showing higher hemicellulose content, its predictive value greatly increases $\left(\mathrm{R}^{2}=0.90-0.94\right)$, suggesting that this fiber component is more biodegradable than cellulose and lignin.

Our observations are in agreement with previous research in which hemicellulose was found to be more biodegradable than cellulose in experiments carried out with water hyacinth and Bermuda grass [54]. It has also been reported that hemicellulose needs to be degraded first, followed by cellulose, according to its location within the lignocellulose matrix [55]. From the abovementioned, it appears logical that an individual term for hemicellulose content is not required within a mathematical equation linking $B_{o}$ with substrate composition, whereas it is required when linking lignocellulose matrix to hydrolysis rates [49].

The use of the empirical model (Equation (5)) requires a third of the experimental effort for validation, as only the ADF fraction, representing lignin plus cellulose, needs to be assessed, thus avoiding the need to separately assess the lignin and NDF amount.

\section{Discussion}

Comparison with previous research. In our here-presented work, it was shown that $B_{o}$ of diverse crop species could be approximated by the use of an empirical model that considers their cellulose and lignin content. It is of interest to study if, when plotting results from previous studies, a similar correlation is found. The anaerobic biodegradability and fiber composition data from previous studies $[22,24,26,28,29,50,54,56]$ are shown in Figure 5a. A great dispersion of data points is found, which does not allow us to establish a singular preferred correlation among the components tested and $B_{0}$, despite an observed negative trend linking $B_{0}$ and lignocellulose content. Three reasons could 
explain this. First, differences in the presence of toxic compounds and the proportion of structural and non-structural components are expected due to the variability in substrate origin and could potentially influence the experimental outcome. Second, the accuracy and reproducibility of the published BMP results need to be reconsidered, as biodegradability assays are influenced by different test conditions [19], particularly inoculum type, particle size, and buffer concentrations [20]. Third, variation is expected with regard to the chemical analysis procedures, particularly those related tothe lignin assessment ones [53].

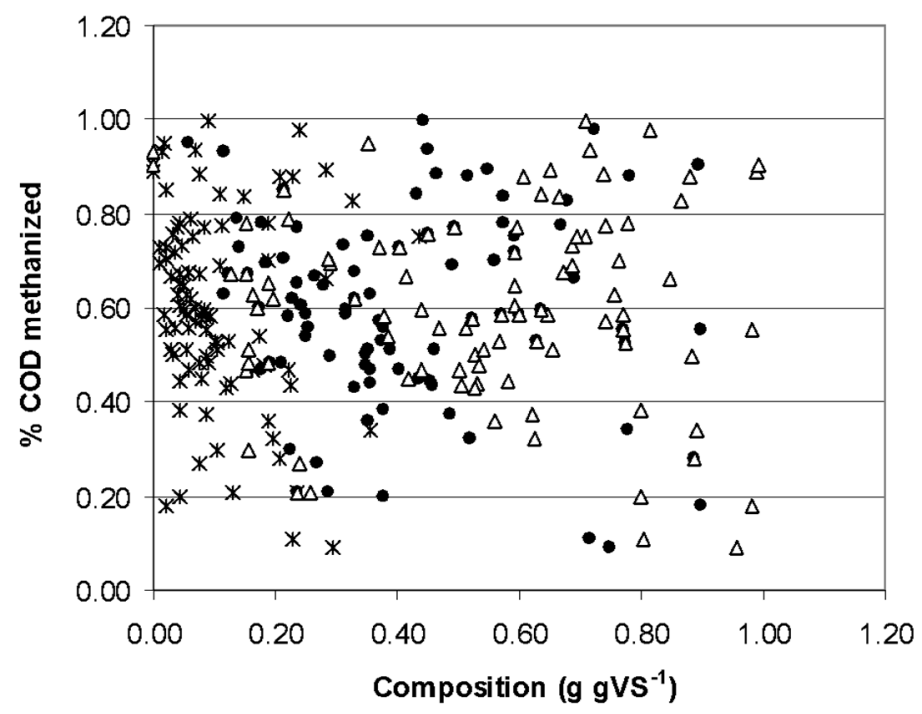

(a)

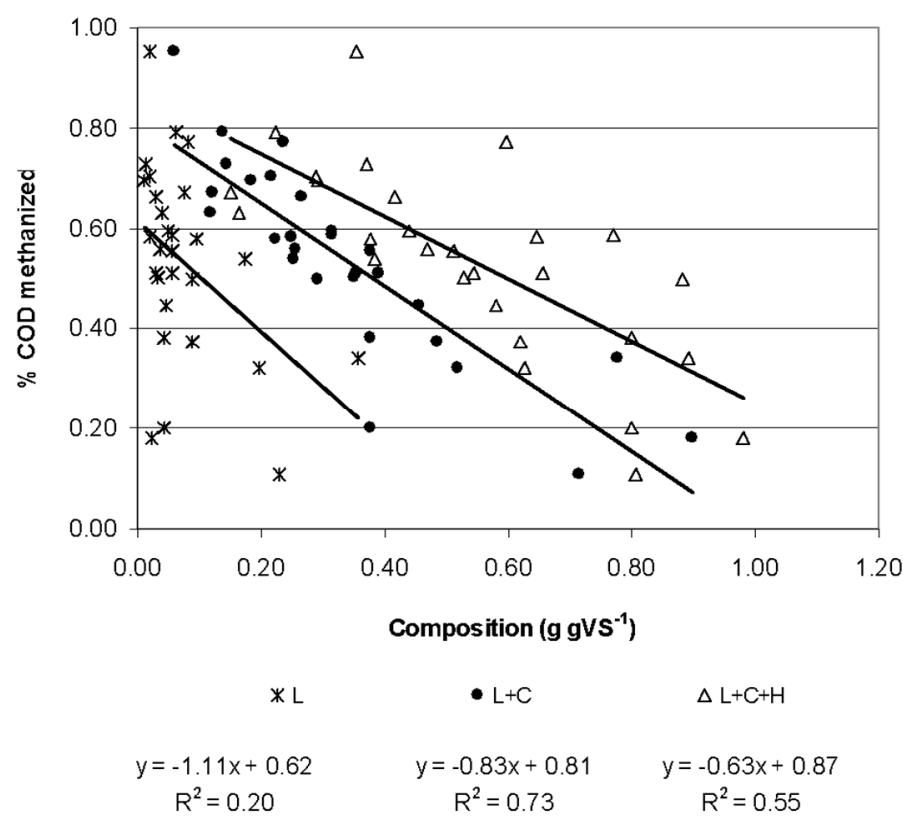

(b)

Figure 5. Cont. 


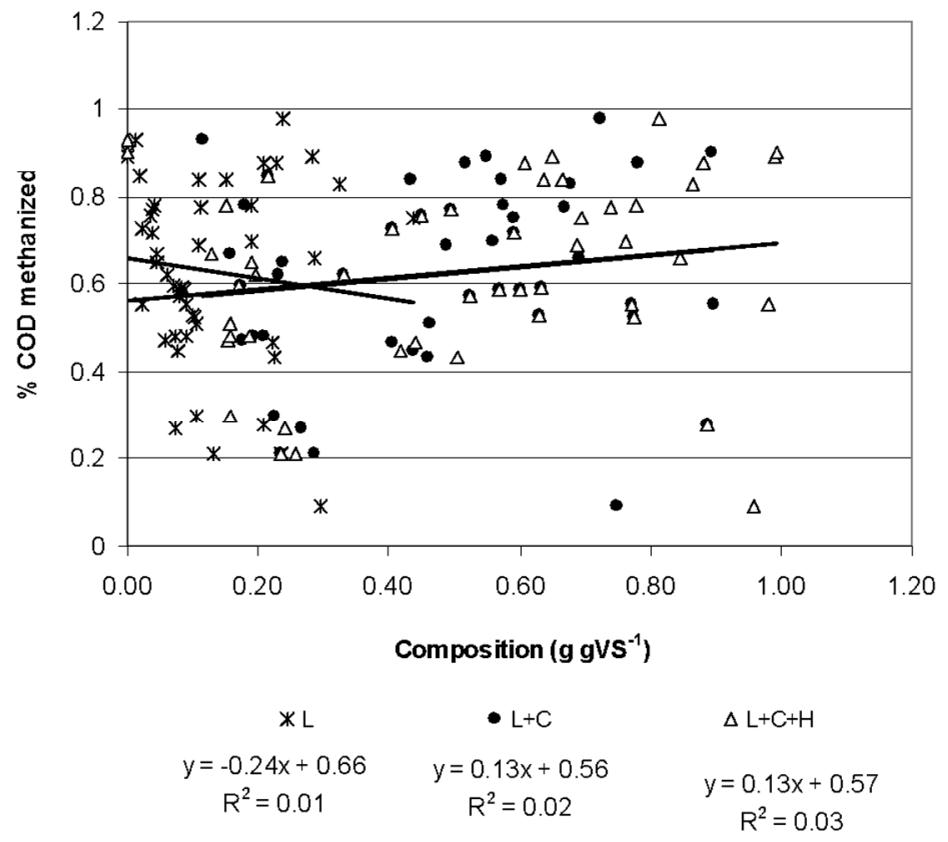

(c)

Figure 5. Relationship between anaerobic biodegradability $\left(B_{0}\right)$ and substrate composition, using data from previous studies (from top to bottom: (a) data from References $[22,24,26,28,29,50,54,56]$; (b) data from three studies using van Soest method for substrate characterization $[50,54,56]$ and this research; (c) data from studies using methods different from van Soest [22,24,26,28,29].

On the first issue concerning different intrinsic sample composition, indeed, previous research has dealt material with different precedence such as manure and plant material [28], woody biomass [29], newspaper [24], and solid residues [26,50], and hence, apart from the fiber composition influence, other inhibitory compounds could be the case. Especially with regard to lignin, a wider spectrum of variation in plant sample composition is found in previous research, reaching up to $0.5 \mathrm{~g} \mathrm{gVS}^{-1}$. Overall, a majority of the samples are below $0.3 \mathrm{~g} \mathrm{gVS}^{-1}$, and in our research, the plant with the highest lignin content was bracken, with $0.2 \mathrm{~g} \mathrm{gVS}^{-1}$, with the majority of our samples being below $0.09 \mathrm{~g} \mathrm{gVS}^{-1}$, which is typical for crops, as can be seen in Table A1, Appendix A.

In regard to the influence of the BMP test, indeed, our test protocol was optimized to deliver the maximum possible biodegradability results, minimizing the interference of aspects such as poor or very specific inoculum activity (i.e., by means of mixing granular and flocculent inoculum), inhibitory phosphate buffer concentrations, and sample particle size (see previous research by the author [20]. Previous research has pointed out the important interference of particle size for samples of more than $1 \mathrm{~mm}$ in size. Palmowski and Muller [57] found total biogas production of hay and sunflower seeds to increase up to $20 \%$ by comminution, concluding that, for substrates with a high content of fibers and a low degradability, their comminution yields to an improved digester gas production. Similarly, Chynoweth and Jerger [30] showed an approximate 18\% increase in the final methane yield of hybrid poplar when reducing particle size from $\leq 8$ to $\leq 0.8 \mathrm{~mm}$. Sharma et al. [31] found an increase of $56 \%$ in the maximum methane yield of grass samples when diminishing particle size from 30 to $1 \mathrm{~mm}$. In our research, particle size interference was minimized by means of the freeze-drying and comminution procedure, which allow for all samples tested to have a similar number of suitable sites for enzymatic attack, thereby allowing for plant screening independently of this variable. Further research is needed to further elucidate the role of lignin in the anaerobic biodegradability of samples with different proportion of biodegradable material and lignin at different particle sizes.

Regarding methods used for fiber analysis, apart from van Soest, other methods for the evaluation of structural components of lignocelluloses material are available and have been used in the previous 
studies, i.e., Klasson lignin, TAPPI, Near Infrared Resonance (NIR), and Nuclear Magnetic Resonance (NMR). These methods deliver different quantitative estimates, with their accuracy depending largely on the type of crop, its crude protein content, and potential soluble lignin [58,59]. Whereas Pareek [56], Ghosh et al. [54], and Buffiere et al. [50] have used the ADL method, as in this study, Chandler et al. [22], Moller et al. [29], and Eleazer et al. [26] used the Klason or 72\% sulphuric acid method for lignin determination. When attempting to plot only the data of studies using the van Soest method (Figure 5b), we found that the correlation between biodegradability and lignin plus cellulose content becomes much stronger, whereas when plotting results from studies using other methods (Figure 5c), we did not find correlations. Hence, although residues other than plant material are included, and differences in methods for BMP determination are also expected, the type of chemical analysis procedure used for sample characterization is found to be of great significance.

Using the ADF Model for $\boldsymbol{B}_{\boldsymbol{o}}$ estimation. The equations presented in this study strive to give an indication on the maximum achievable anaerobic biodegradability of plant material under applied optimal conditions in dependence to the fiber composition. They are useful for screening for the material best suitable for anaerobic digestion from the perspective of their maximum intrinsic energy potential.

The ADF model (Equation (5)) was further used to predict the anaerobic biodegradability of other material suitable for building sustainable crop rotations. The database employed was the one reported in the study by Stenberg et al. [60], containing 114 lignocellulosic samples characterized by using the van Soest method for fiber analyses. The database contains Northern European agricultural plants and anatomical components, including cereals, pasture grasses, legumes, vegetables, fiber crops, energy crops, and catch crops. The variation of sample composition was similar to that of our research, with $\mathrm{NDF}, \mathrm{ADF}$, and ADL varying in the ranges $0.15-0.83,0.07-0.65$, and $0.01-0.17 \mathrm{~g} \mathrm{gTS}^{-1}$, with average values of $0.51,0.33$, and $0.04 \mathrm{~g} \mathrm{gTS}^{-1}$, respectively. By using Equation (5), we found that the average predicted anaerobic biodegradability of the 114 samples was $53 \%$, with minimum and maximum values being $21 \%$ and $79 \%$, respectively. In this way, the screening quality of the equation proposed clearly allows for the discrimination of plants more anaerobically biodegradable under the optimized test conditions.

Clear differences were also found amongst different plant parts when working with the database. The average biodegradability of green leaves, mature straw, pods, stems, and whole plants was $63 \%$, $39 \%, 71 \%, 44 \%$, and 53\%, respectively. As known, crop residues like straws and stems have, in general, a low anaerobic potential per unit solids. Nonetheless, and interestingly, the pods of barley and maize, along with the green leaves of oilseed rape, sugar beet, carrot, and hemp, were found to be the most promising ago-residual substrates, showing between $70 \%$ and $79 \%$ anaerobic biodegradability. Therefore, it is shown that a choice for residues instead of plants competing with food is still possible without compromising methane yield per unit solids. Among whole-plant samples, legumes and grasses showed the highest anaerobic biodegradability, yet it is possible to find other agricultural crops, like oilseed rape, to be similarly suited, from the perspective of their anaerobic biodegradability. The database and predicted biodegradability are available in Table A1, Appendix A.

\section{Concluding Remarks}

Based on fifteen European plant species, a statistical model for the estimation of the anaerobic biodegradability of plant material was developed. This new approach represents an accurate and cost-effective method for identifying valuable energy plants for sustainable energy production.

Anaerobic biodegradability of lignocellulosic material was empirically found to be related to the amount of cellulose plus lignin, as analytically assessed by the van Soest method, i.e., the ADF value. In particular, our calculations found correlations between the ultimate anaerobic biodegradability $\left(B_{0}\right)$ and chemical composition of plant material, using freeze-dried and comminuted samples, striving for simpler ways of screening for suitable biomass for anaerobic digestion. Results indicate a reciprocal correlation $\left(\mathrm{R}^{2}=0.86, \mathrm{t}<0.0001\right)$ between $B_{o}$ and the sum lignin plus cellulose, as given by the acid detergent fiber (ADF) method. Model equations including more variables like hemicellulose, crude 
protein, or starch show a similar predictive value $\left(R^{2}=0.87-0.88\right)$ but lower significance $(t>0.1)$. Results indicate that the lignin content, as measured by the acid detergent lignin (ADL) method, does not accurately predict $B_{o}\left(R^{2}=0.61\right)$. Among the models developed, those omitting hemicellulose showed a higher predictive value. The latter can be attributed to the higher hemicellulose anaerobic conversion and the fact that it needs to be degraded prior to cellulose.

Apart from being theoretically meaningful, the ADF-based empirical model requires the least effort compared to the conceptual models, as individual fractions of cellulose, hemicellulose, and lignin do not need to be assessed, thus enhancing the accuracy of the model's estimation. The model also showed to be valid when biodegradability data from previous studies performing the van Soest sample characterization were employed.

Author Contributions: Conceptualization, C.P.P.-P. and J.B.v.L.; methodology, C.P.P.-P.; validation, H.V.M.H.; formal analysis, C.P.P.-P.; investigation, C.P.P.-P. and I.M.; writing-original draft preparation, C.P.P.-P.; writing - review and editing, J.B.v.L.; supervision, J.B.v.L.; project administration, J.B.v.L.; funding acquisition, J.B.v.L. All authors have read and agreed to the published version of the manuscript.

Funding: This research received funding from the EUProject CROPGEN.

Acknowledgments: The authors gratefully acknowledge the contribution of $B_{0}$ Stenberg and colleagues from the Division of Precision Agriculture, Department of Soil Science of the Swedish University of Agricultural Sciences, for providing their database used in the discussion. They further acknowledge the EU project "Renewable energy from crops and agrowastes (CROPGEN)", contract SES6-CT-2004-502824, for financial support. The authors extend their gratitude to Vinnie de Wilde, Ardy Beurskens, Jean Slangen, and Gabi Stiebe for analytical assistance.

Conflicts of Interest: The authors declare no conflict of interest. 


\section{Appendix A}

Additional Information Predicting Biodegradability of 114 Northern European Plant Samples.

Table A1. Classification, van Soest analysis, and predicted biodegradability $\left(B_{o}\right)$ of 114 Northern European Plant samples (data from Reference [60]. ( $B_{o}$ was predicted by assuming an average VS value of $92 \% \mathrm{TS}$, as assessed in this study).

\begin{tabular}{|c|c|c|c|c|c|c|c|}
\hline English Name & Latin Name & Plant Class & Plant Part & NDF $g_{\text {gDM }}{ }^{-1}$ & ADF g gDM $^{-1}$ & ADL g gDM $^{-1}$ & Predicted $B_{o} \% \mathrm{COD}$ \\
\hline Barley & Hordeum vulgare distichon & Cereals & Green leaves & 772.9 & 431.1 & 25.6 & $43 \%$ \\
\hline Wheat & Triticum aestivum & Cereals & Green leaves & 748.4 & 423.9 & 51.9 & $44 \%$ \\
\hline Wheat & Triticum aestivum & Cereals & Green leaves & 689.3 & 402.2 & 32.6 & $46 \%$ \\
\hline Barley & Hordeum vulgare distichon & Cereals & Green leaves & 645.9 & 367.7 & 26.7 & $49 \%$ \\
\hline Elephant Grass & Miscanthus gigantus & Alternative crops & Green leaves & 704.1 & 356.5 & 20.5 & $50 \%$ \\
\hline Barley & Hordeum vulgare distichon & Cereals & Green leaves & 691.0 & 355.9 & 22.9 & $50 \%$ \\
\hline Wheat & Triticum aestivum & Cereals & Green leaves & 671.8 & 350.9 & 55.1 & $51 \%$ \\
\hline Bent grass & Agrostis capillaris & Grasses & Green leaves & 443.1 & 333.2 & 60.7 & $53 \%$ \\
\hline Meadow Fescue & Festuca pratensis & Grasses & Green leaves & 482.9 & 279.2 & 15.2 & $58 \%$ \\
\hline Maize & Zea mays & Other agric. crops & Green leaves & 588.6 & 277.3 & 5.8 & $58 \%$ \\
\hline Cock's-Foot & Dactylis glomerata & Grasses & Green leaves & 535.9 & 276.9 & 14.4 & $58 \%$ \\
\hline Onion & Allium сера & Horticultural crops & Green leaves & 352.3 & 276.1 & 72.9 & $58 \%$ \\
\hline Oats & Avena sativa & Cereals & Green leaves & 482.6 & 274.2 & 25.5 & $59 \%$ \\
\hline Winter Rye & Secale cereale & Cereals & Green leaves & 447.7 & 255.9 & 34.5 & $60 \%$ \\
\hline Oil Radish & Raphanus sativus & Catch crops & Green leaves & 247.5 & 250.8 & 30.8 & $61 \%$ \\
\hline Cock's-Foot & Dactylis glomerata & Grasses & Green leaves & 474.3 & 245.4 & 14.9 & $61 \%$ \\
\hline Yellow Lupin & Lupinus luteus & Legumes & Green leaves & 301.9 & 224.6 & 28.4 & $64 \%$ \\
\hline Chicory & Cichorium intybus & Catch crops & Green leaves & 214.2 & 218.9 & 16.6 & $64 \%$ \\
\hline English Ryegrass & Lolium perenne & Grasses & Green leaves & 410.9 & 213.7 & 10.5 & $65 \%$ \\
\hline Barley & Hordeum vulgare distichon & Cereals & Green leaves & 362.8 & 210.2 & 15.1 & $65 \%$ \\
\hline Flax & Linum usitatissimum & Alternative crops & Green leaves & 303.3 & 198.8 & 65.9 & $66 \%$ \\
\hline Oats & Avena sativa & Cereals & Green leaves & 352.8 & 188.0 & 4.4 & $67 \%$ \\
\hline Hemp & Cannabis sativa & Alternative crops & Green leaves & 224.3 & 172.5 & 35.8 & $69 \%$ \\
\hline Leek & Allium porrum & Horticultural crops & Green leaves & 211.8 & 170.7 & 16.5 & $69 \%$ \\
\hline Carrot & Daucus carota & Horticultural crops & Green leaves & 216.6 & 156.2 & 31.0 & $70 \%$ \\
\hline Chicory & Cichorium intybus & Catch crops & Green leaves & 198.7 & 152.6 & 11.4 & $71 \%$ \\
\hline Cabbage & Brassica oleracea & Horticultural crops & Green leaves & 196.8 & 147.4 & 2.0 & $71 \%$ \\
\hline Phacelia & Phacelia tanacetifolia & Catch crops & Green leaves & 242.6 & 144.0 & 18.7 & $72 \%$ \\
\hline Alfalfa/Lucerne & Medicago sativa & Legumes & Green leaves & 194.6 & 141.1 & 15.7 & $72 \%$ \\
\hline Crimson Clover & Trifolium incarnatum & Legumes & Green leaves & 224.6 & 134.4 & 11.3 & $73 \%$ \\
\hline
\end{tabular}


Table A1. Cont.

\begin{tabular}{|c|c|c|c|c|c|c|c|}
\hline English Name & Latin Name & Plant Class & Plant Part & NDF $g_{\text {gDM }}{ }^{-1}$ & ADF g gDM $^{-1}$ & ADL $g_{\text {gDM }}{ }^{-1}$ & Predicted $B_{o} \%$ COD \\
\hline Oilseed Rape & Brassica napus oleifera & Other agric. crops & Green leaves & 245.4 & 126.2 & 19.9 & $73 \%$ \\
\hline Oilseed Rape & Brassica napus oleifera & Other agric. crops & Green leaves & 169.9 & 124.9 & 0.6 & $74 \%$ \\
\hline Sugar Beet & Beta vulgaris spp. & Other agric. crops & Green leaves & 231.3 & 123.6 & 6.1 & $74 \%$ \\
\hline White Clover & Trifolium repens & Legumes & Green leaves & 153.6 & 105.0 & 9.1 & $76 \%$ \\
\hline Cabbage & Brassica oleracea & Horticultural crops & Green leaves & 150.3 & 102.7 & 0.9 & $76 \%$ \\
\hline Turnip Rape & Brassica rapa oleifera & Catch crops & Green leaves & 181.7 & 95.3 & 7.7 & $76 \%$ \\
\hline Sunflower & Helianthus ... & Other agric. crops & Mature straw & 742.1 & 627.5 & 115.0 & $23 \%$ \\
\hline Hemp & Cannabis sativa & Alternative crops & Mature straw & 700.0 & 589.1 & 88.1 & $27 \%$ \\
\hline Turnip Rape & Brassica rapa oleifera & Catch crops & Mature straw & 763.4 & 584.5 & 126.5 & $28 \%$ \\
\hline Pea & Pisum sativum & Legumes & Mature straw & 766.5 & 563.9 & 107.1 & $30 \%$ \\
\hline Pea & Pisum sativum & Legumes & Mature straw & 749.5 & 548.9 & 111.8 & $31 \%$ \\
\hline Yellow Mustard & Sinapis alba & Catch crops & Mature straw & 727.3 & 509.5 & 113.7 & $35 \%$ \\
\hline Barley & Hordeum vulgare distichon & Cereals & Mature straw & 817.3 & 473.4 & 44.8 & $39 \%$ \\
\hline Wheat & Triticum aestivum & Cereals & Mature straw & 791.9 & 457.0 & 36.6 & $40 \%$ \\
\hline Wheat & Triticum aestivum & Cereals & Mature straw & 754.3 & 448.5 & 47.3 & $41 \%$ \\
\hline Barley & Hordeum vulgare distichon & Cereals & Mature straw & 673.7 & 406.6 & 40.2 & $45 \%$ \\
\hline Red Fescue & Festuca rubra & Grasses & Mature straw & 717.6 & 403.9 & 42.6 & $46 \%$ \\
\hline Meadow Foxtail & Alopecurus pratensis & Grasses & Mature straw & 675.9 & 358.5 & 25.4 & $50 \%$ \\
\hline Bluegrass & Poa pratensis & Grasses & Mature straw & 650.7 & 341.3 & 23.6 & $52 \%$ \\
\hline Oats & Avena sativa & Cereals & Mature straw & 543.2 & 306.2 & 20.5 & $55 \%$ \\
\hline Oilseed Rape & Brassica napus oleifera & Other agric. crops & Pod walls & 567.0 & 428.6 & 90.0 & $43 \%$ \\
\hline Oilseed Rape & Brassica napus oleifera & Other agric. crops & Pod walls & 529.1 & 390.9 & 72.4 & $47 \%$ \\
\hline Maize & Zea mays & Other agric. crops & Pods & 509.2 & 230.5 & 3.4 & $63 \%$ \\
\hline Wheat & Triticum aestivum & Cereals & Pods & 394.3 & 193.7 & 20.9 & $67 \%$ \\
\hline Barley & Hordeum vulgare distichon & Cereals & Pods & 480.6 & 175.5 & 11.3 & $68 \%$ \\
\hline Wheat & Triticum aestivum & Cereals & Pods & 287.6 & 126.7 & 11.4 & $73 \%$ \\
\hline Barley & Hordeum vulgare distichon & Cereals & Pods & 251.9 & 76.2 & 3.2 & $78 \%$ \\
\hline Maize & Zea mays & Other agric. crops & Pods & 197.1 & 68.9 & 0.7 & $79 \%$ \\
\hline Hemp & Cannabis sativa & Alternative crops & Stem & 794.9 & 649.3 & 100.4 & $21 \%$ \\
\hline Flax & Linum usitatissimum & Alternative crops & Stem & 765.2 & 629.1 & 168.0 & $23 \%$ \\
\hline Flax & Linum usitatissimum & Alternative crops & Stem & 677.1 & 576.7 & 138.7 & $28 \%$ \\
\hline Flax & Linum usitatissimum & Alternative crops & Stem & 730.8 & 563.8 & 166.3 & $30 \%$ \\
\hline Oilseed Rape & Brassica napus oleifera & Other agric. crops & Stem & 731.3 & 554.8 & 113.5 & $31 \%$ \\
\hline
\end{tabular}


Table A1. Cont.

\begin{tabular}{|c|c|c|c|c|c|c|c|}
\hline English Name & Latin Name & Plant Class & Plant Part & NDF $g_{\text {gDM }}{ }^{-1}$ & ADF g gDM $^{-1}$ & ADL $g g^{-1}$ & Predicted $B_{o} \%$ COD \\
\hline Oilseed Rape & Brassica napus oleifera & Other agric. crops & Stem & 719.9 & 544.8 & 106.7 & $32 \%$ \\
\hline Elephant Grass & Miscanthus gigantus & Alternative crops & Stem & 785.8 & 518.2 & 60.0 & $34 \%$ \\
\hline Barley & Hordeum vulgare distichon & Cereals & Stem & 828.2 & 515.5 & 69.3 & $34 \%$ \\
\hline Wheat & Triticum aestivum & Cereals & Stem & 816.6 & 510.3 & 50.7 & $35 \%$ \\
\hline Wheat & Triticum aestivum & Cereals & Stem & 819.0 & 506.6 & 76.7 & $35 \%$ \\
\hline Wheat & Triticum aestivum & Cereals & Stem & 797.8 & 469.2 & 94.7 & $39 \%$ \\
\hline Barley & Hordeum vulgare distichon & Cereals & Stem & 767.6 & 464.3 & 41.6 & $40 \%$ \\
\hline Yellow Lupin & Lupinus luteus & Legumes & Stem & 537.6 & 454.6 & 74.2 & $41 \%$ \\
\hline Alfalfa/Lucerne & Medicago sativa & Legumes & Stem & 559.2 & 444.6 & 111.0 & $42 \%$ \\
\hline Red Clover & Trifolium pratense & Legumes & Stem & 514.8 & 406.3 & 65.4 & $45 \%$ \\
\hline Cock's-Foot & Dactylis glomerata & Grasses & Stem & 659.4 & 364.3 & 25.8 & $50 \%$ \\
\hline Cock's-Foot & Dactylis glomerata & Grasses & Stem & 638.3 & 355.0 & 22.0 & $51 \%$ \\
\hline Wheat & Triticum aestivum & Cereals & Stem & 617.2 & 355.0 & 60.4 & $51 \%$ \\
\hline Maize & Zea mays & Other agric. crops & Stem & 596.3 & 344.3 & 14.9 & $52 \%$ \\
\hline Persian Clover & Trifolium resupinatum & Legumes & Stem & 440.0 & 339.4 & 85.4 & $52 \%$ \\
\hline Wheat & Triticum aestivum & Cereals & Stem & 572.6 & 337.9 & 36.2 & $52 \%$ \\
\hline Barley & Hordeum vulgare distichon & Cereals & Stem & 629.7 & 332.4 & 23.1 & $53 \%$ \\
\hline Maize & Zea mays & Other agric. crops & Stem & 566.4 & 329.1 & 14.7 & $53 \%$ \\
\hline Maize & Zea mays & Other agric. crops & Stem & 581.2 & 329.1 & 16.6 & $53 \%$ \\
\hline Bent Grass & Agrostis capillaris & Grasses & Stem & 393.5 & 313.0 & 49.7 & $55 \%$ \\
\hline Wheat & Triticum aestivum & Cereals & Stem & 498.4 & 290.6 & 23.4 & $57 \%$ \\
\hline English Ryegrass & Lolium perenne & Grasses & Stem & 494.0 & 256.0 & 6.7 & $60 \%$ \\
\hline White Clover & Trifolium repens & Legumes & Stem & 239.4 & 181.2 & 17.3 & $68 \%$ \\
\hline Red Clover & Trifolium pratense & Legumes & Stem & 277.3 & 176.2 & 24.3 & $68 \%$ \\
\hline Flax & Linum usitatissimum & Alternative crops & Whole plant & 708.0 & 585.1 & 125.0 & $28 \%$ \\
\hline Broad Bean & Vicia faba & Legumes & Whole plant & 636.4 & 527.1 & 97.9 & $33 \%$ \\
\hline Barley & Hordeum vulgare distichon & Cereals & Whole plant & 816.4 & 512.2 & 54.8 & $35 \%$ \\
\hline Black Mustard & & Other agric. crops & Whole plant & 629.7 & 481.7 & 87.8 & $38 \%$ \\
\hline Flax & Linum usitatissimum & Alternative crops & Whole plant & 613.9 & 466.8 & 111.0 & $39 \%$ \\
\hline Flax & Linum usitatissimum & Alternative crops & Whole plant & 525.0 & 383.8 & 96.9 & $48 \%$ \\
\hline Oil Radish & Raphanus sativus & Catch crops & Whole plant & 450.5 & 383.1 & 64.5 & $48 \%$ \\
\hline Ribbed Melilot & Melilotus officinalis & Legumes & Whole plant & 435.4 & 379.0 & 64.9 & $48 \%$ \\
\hline Bluegrass & Poa pratensis & Grasses & Whole plant & 661.3 & 375.0 & 25.2 & $49 \%$ \\
\hline
\end{tabular}


Table A1. Cont.

\begin{tabular}{|c|c|c|c|c|c|c|c|}
\hline English Name & Latin Name & Plant Class & Plant Part & NDF g gDM $^{-1}$ & ADF g gDM $^{-1}$ & ADL $g_{g^{\prime}} \mathrm{gM}^{-1}$ & Predicted $B_{o} \% \mathrm{COD}$ \\
\hline Common Bird's-Foot-Trefoil & Lotus corniculatus & Legumes & Whole plant & 461.1 & 359.1 & 87.6 & $50 \%$ \\
\hline Tall Fescue & ?? Pratense & Grasses & Whole plant & 585.2 & 346.3 & 32.0 & $51 \%$ \\
\hline Timothy & Phleum pratense & Grasses & Whole plant & 612.6 & 333.2 & 18.8 & $53 \%$ \\
\hline Maize & Zea mays & Other agric. crops & Whole plant & 688.3 & 332.2 & 7.7 & $53 \%$ \\
\hline Cock's-Foot & Dactylis glomerata & Grasses & Whole plant & 571.1 & 324.1 & 16.0 & $54 \%$ \\
\hline Maize & Zea mays & Other agric. crops & Whole plant & 676.5 & 317.6 & 1.1 & $54 \%$ \\
\hline Tall Fescue & ?? Pratense & Grasses & Whole plant & 507.5 & 294.0 & 20.1 & $57 \%$ \\
\hline English Ryegrass & Lolium perenne & Grasses & Whole plant & 514.5 & 273.8 & 21.9 & $59 \%$ \\
\hline Crimson Clover & Trifolium incarnatum & Legumes & Whole plant & 435.5 & 273.1 & 57.7 & $59 \%$ \\
\hline Timothy & Phleum pratense & Grasses & Whole plant & 511.7 & 271.8 & 14.1 & $59 \%$ \\
\hline Winter Vetch & Vicia villosa & Legumes & Whole plant & 344.0 & 262.3 & 50.5 & $60 \%$ \\
\hline Alfalfa/Lucerne & Medicago sativa & Legumes & Whole plant & 336.1 & 255.5 & 44.7 & $60 \%$ \\
\hline Egyptian Clover & Trifolium alexandrinum & Legumes & Whole plant & 342.8 & 244.8 & 35.0 & $62 \%$ \\
\hline White Clover & Trifolium repens & Legumes & Whole plant & 314.3 & 226.7 & 63.9 & $63 \%$ \\
\hline Crimson Clover & Trifolium incarnatum & Legumes & Whole plant & 310.4 & 220.9 & 24.4 & $64 \%$ \\
\hline White Clover & Trifolium repens & Legumes & Whole plant & 247.2 & 198.9 & 48.1 & $66 \%$ \\
\hline Red Clover & Trifolium pratense & Legumes & Whole plant & 267.4 & 195.1 & 19.8 & $67 \%$ \\
\hline Oilseed Rape & Brassica napus oleifera & Other agric. crops & Whole plant & 247.1 & 184.0 & 13.6 & $68 \%$ \\
\hline
\end{tabular}




\section{References}

1. Berglund, M.; Börjesson, P. Assessment of energy performance in the life-cycle of biogas production. Biomass and Bioenergy 2006, 30, 254-266. [CrossRef]

2. Lehtomaki, A.; Viinikainen, T.A.; Rintala, J.A. Screening Boreal energy crops and crop residues for methane biofuel production. Biomass Bioenergy 2008, 32, 541-550. [CrossRef]

3. Pabón-Pereira, C.; Slingerland, M.; Hogervorst, S.; van Lier, J.; Rabbinge, R. A sustainability assessment of bioethanol (EtOH) production: The case of cassava in Colombia. Sustainability 2019, 11, 3968. [CrossRef]

4. Chynoweth, D.; Owens, J.; Legrand, R. Renewable methane from anaerobic digestion of biomass. Renew. Energy 2001, 22, 1-8. [CrossRef]

5. Lehtomaki, A.; Huttunen, S.; Rintala, J.A. Laboratory investigations on co-digestion of energy crops and crop residues with cow manure for methane production: Effect of crop to manure ratio. Resour. Conserv. Recycl. 2007, 51, 591-609. [CrossRef]

6. Weiland, P. Production and energetic use of biogas from energy crops and wastes in Germany. Appl. Biochem. Biotechnol. 2003, 109, 263-274. [CrossRef]

7. Vats, N.; Khan, A.A.; Ahmad, K. Effect of substrate ratio on biogas yield for anaerobic co-digestion of fruit vegetable waste \& sugarcane bagasse. Environ. Technol. Innov. 2019, 13, 331-339.

8. Asquer, C.; Pistis, A.; Scano, E.A. Characterization of Fruit and Vegetable Wastes as a Single Substrate for the Anaerobic Digestion Extended Abstract. Environ. Eng. Manag. J. 2013, 12, 89-92.

9. Bangalore, M.; Hochman, G.; Zilberman, D. Policy incentives and adoption of agricultural anaerobic digestion: A survey of Europe and the United States. Renew. Energy 2016, 97, 559-571. [CrossRef]

10. Banks, C.J.; Salter, A.M.; Chesshire, M. Potential of anaerobic digestion for mitigation of greenhouse gas emissions and production of renewable energy from agriculture: Barriers and incentives to widespread adoption in Europe. Water Sci. Technol. 2007, 55, 165-173. [CrossRef]

11. Yang, L.; Xu, F.; Ge, X.; Li, Y. Challenges and strategies for solid-state anaerobic digestion of lignocellulosic biomass. Renew. Sustain. Energy Rev. 2015, 44, 824-834. [CrossRef]

12. Sawatdeenarunat, C.; Surendra, K.C.; Takara, D.; Oechsner, H.; Khanal, S.K. Anaerobic digestion of lignocellulosic biomass: Challenges and opportunities. Bioresour. Technol. 2015, 178, 178-186. [CrossRef] [PubMed]

13. Amon, T.; Amon, B.; Kryvoruchko, V.; Machmuller, A.; Hopfner-Sixt, K.; Bodiroza, V.; Hrbek, R.; Friedel, J.; Potsch, E.; Wagentristl, H.; et al. Methane production through anaerobic digestion of various energy crops grown in sustainable crop rotations. Bioresour. Technol. 2007, 98, 3204-3212. [CrossRef] [PubMed]

14. Boehmel, C.; Lewandowski, I.; Claupein, W. Comparing annual and perennial energy cropping systems with different management intensities. Agric. Syst. 2008, 96, 224-236. [CrossRef]

15. Nemecek, T.; von Richthofen, J.S.; Dubois, G.; Casta, P.; Charles, R.; Pahl, H. Environmental impacts of introducing grain legumes into European crop rotations. Eur. J. Agron. 2008, 28, 380-393. [CrossRef]

16. Gunaseelan, N. Anaerobic Digestion of Biomass for Methane Production: A Review. Biomass Bioenergy 1997, 13, 83-114. [CrossRef]

17. Lehtomaki, A. Biogas Production from Energy Crops and Crop Residues; Department of Biological and Environmental Science, Jyvaskyla University: Jyvaskyla, Finland, 2006; p. 91.

18. Angelidaki, I.; Sanders, W. Assessment of the anaerobic biodegradability of macropollutants. Rev. Environ. Sci. Biotechnol. 2004, 3, 117-129. [CrossRef]

19. Holliger, C.; Alves, M.; Andrade, D.; Angelidaki, I.; Astals, S.; Baier, U.; Bougrier, C.; Buffière, P.; Carballa, M.; De Wilde, V.; et al. Towards a standardization of biomethane potential tests. Water Sci. Technol. 2016, 74, 2515-2522. [CrossRef]

20. Pabón-Pereira, C.; Castanares, G.; Van Lier, J. An OxiTop®protocol for screening plant material for its biochemical methane potential (BMP). Water Sci. Technol. 2012, 66, 1416-1423. [CrossRef]

21. Angelidaki, I.; Alves, M.; Bolzonella, D.; Borzacconi, L.; Campos, J.L.; Guwy, A.; Kalyuzhnyi, S.; Jenicek, P.; Van Lier, J.B. Defining the biomethane potential (BMP) of solid organic wastes and energy crops: A proposed protocol for batch assays. Water Sci. Technol. 2009, 59, 927-934. [CrossRef]

22. Chandler, J.A.; Jewell, W.J.; Gossett, J.M.; Van Soest, P.J.; Robertson, J.B. Predicting methane fermentation biodegradability. Biotechnol. Bioeng. Symp. 1980, 10, 93-107. 
23. Jimenez, S.; Cartagena, M.C.; Arce, A. Influence of Lignin on the Methanization of Lignocellulosic Wastes. Biomass 1990, 21, 43-54. [CrossRef]

24. Tong, X.; Smith, L.H.; McCarty, P.L. Methane Fermentation of Selected Lignocellulosic Materials. Biomass 1990, 21, 239-255. [CrossRef]

25. Turick, C.E.; Peck, M.W.; Chynoweth, D.P.; Jerger, D.E.; White, E.H.; Zsuffa, L.; Kenney, W.A. Methane fermentation of woody biomass. Bioresour. Technol. 1991, 37, 141-147. [CrossRef]

26. Eleazer, W.E.; Odle Iii, W.S.; Wang, Y.S.; Barlaz, M.A. Biodegradability of municipal solid waste components in laboratory- scale landfills. Environ. Sci. Technol. 1997, 31, 911-917. [CrossRef]

27. Herrmann, C.; Idler, C.; Heiermann, M. Biogas crops grown in energy crop rotations: Linking chemical composition and methane production characteristics. Bioresour. Technol. 2016, 206, 23-35.

28. Amon, T.; Amon, B.; Kryvoruchko, V.; Zollitsch, W.; Mayer, K.; Gruber, L. Biogas production from maize and dairy cattle manure-Influence of biomass composition on the methane yield. Agric. Ecosyst. Environ. 2007, 118, 173-182. [CrossRef]

29. Moller, H.B.; Sommer, S.G.; Ahring, B.K. Methane productivity of manure, straw and solid fractions of manure. Biomass Bioenergy 2004, 26, 485-495. [CrossRef]

30. Chynoweth, D.P.; Conrad, J.R.; Srivastava, V.J.; Jerger, D.E.; Mensinger, J.D.; Fannin, K.F. Anaerobic processes. J. Water Pollut. Control Fed. 1985, 57, 533-539.

31. Sharma, S.; Mishra, I.M.; Sharma, M.P.; Saini, J.S. Effect of particle size on biogas generation from biomass residues. Biomass 1988, 17, 251-263. [CrossRef]

32. Van Soest, P.J.; Robertson, J.B.; Lewis, B.A. Methods for Dietary Fiber, Neutral Detergent Fiber and Nonstarch Polysaccharides in relation to animal nutrition. J. Dairy Sci. 1991, 74, 3583-3597. [CrossRef]

33. Owen, W.F.; Stuckey, D.C.; Healy, J.B.; Young, L.Y.; McCarty, P.L. Bioassay for monitoring biochemical methane potential and anaerobic toxicity. Water Res. 1979, 13, 485-492. [CrossRef]

34. APHA-American Public Health Association. Standard Methods for the Examination of Water and Wastewater, 20th ed.; American Public Health Association: Washington, DC, USA, 1998.

35. Symons, G.E.; Buswell, A.M. The methane fermentation of carbohydrates. J. Am. Chem. Soc. 1933, 55, 2028-2036. [CrossRef]

36. Undersander, D.; Mertens, D.; Thiex, N. Forage Analyses Procedures; National Forage Testing Association: Omaha, NE, USA, 1993; p. 154.

37. Veeken, A.; Hamelers, B. Effect of temperature on the hydrolysis rate of selected biowaste components. Bioresour. Technol. 1999, 69, 249-255. [CrossRef]

38. Lewis, N.; Yamamoto, E. Lignin: Occurence, biogenesis and biodegradation. Annu. Rev. Plant. Physiol. Plant. Mol. Biol. 1990, 41, 455-496. [CrossRef]

39. Benner, R.; Maccubin, A.E.; Hodson, R.E. Anaerobic biodegradation of the lignin and polysaccharide components of lignocellulose and synthetic lignin by sediment microflora. Appl. Environ. Microbiol. 1984, 47, 998-1004. [CrossRef]

40. Den Camp, H.J.M.O.; Verhagen, F.; Kivaisi, A.K.; Windt, F.D.; Lubberding, H.; Gijzen, H.J.; Vogels, G.D. Effects of lignin on the anaerobic degradation of (ligno) cellulosic wastes by rumen microorganisms. Appl. Microbiol. Biotechnol. 1988, 29, 408-412. [CrossRef]

41. Fernandes, T.V.; Zeeman, G.; van Lier, J.B. Humic acid-like and Fulvic acid-like inhibition on the hydrolysis of cellulose and tributyrin. Bioenergy Res. 2015, 8, 821-831. [CrossRef]

42. Azman, S.; Khadem, A.F.; Zeeman, G.; van Lier, J.B.; Plugge, C.M. Mitigation of humic acid inhibition in anaerobic cellulose digestion by addition of cationic salts. Bioengineering 2015, 2, 54-65. [CrossRef] [PubMed]

43. Ghasimi, D.S.M.; Zandvoort, K.A.M.d.M.H.; van Lier, J.B. Impact of lignocellulosic-waste intermediates on hydrolysis and methanogenesis under thermophilic and mesophilic conditions. Chem. Eng. J. 2015, 295, 181-191. [CrossRef]

44. Wang, Y.S.; Byrd, C.S.; Barlaz, M.A. Anaerobic biodegradability of cellulose and hemicellulose in excavated refuse samples using a biochemical methane potential assay. J. Ind. Microbiol. 1994, 13, 147-193. [CrossRef] [PubMed]

45. Triolo, J.M.; Sommer, S.G.; Møller, H.B.; Weisbjerg, M.R.; Jiang, X.Y. A new algorithm to characterize biodegradability of biomass during anaerobic digestion: Influence of lignin concentration on methane production potential. Bioresour. Technol. 2011, 102, 9395-9402. [CrossRef] [PubMed] 
46. Chynoweth, D.P.; Turick, C.E.; Owens, J.M.; Jerger, D.E.; Peck, M.W. Biochemical Methane Potential of biomass and waste feedstocks. Biomass Bioenergy 1993, 5, 95-111. [CrossRef]

47. Barton, F.E.I.; Akin, D.E. Digestibility of delignified forage cell walls. J. Agric. Food Chem. 1977, 25, $1299-1303$. [CrossRef]

48. Selinger, L.B.; Forsberg, C.W.; Cheng, K.J. The rumen: A unique source of enzymes for enhancing livestock production. Anaerobe 1996, 2, 263-284. [CrossRef]

49. Pabón Pereira, C.P. Anaerobic Digestion in Sustainable Biomass Chains; Wageningen University: Wageningen, The Netherlands, 2009.

50. Buffiere, P.; Loisel, D.; Bernet, N.; Delgenes, J.P. Towards new indicators for the prediction of solid waste anaerobic digestion properties. Water Sci. Technol. 2006, 53, 233-241. [CrossRef]

51. Conrad, H.R.; Weiss, W.P.; Odwongo, W.O.; Shockey, W.L. Estimating Net Energy of Lactation from components of cell solubles and cell walls. J. Dairy Sci. 1984, 67, 427-436. [CrossRef]

52. Noike, T.; Endo, G.; Chang, J.; Yaguchi, J.; Matsumoto, J. Characteristics of Carbo hydrate degradation and the rate limiting step in anaerobic digestion. Biotechnol. Bioeng. 1985, 27, 1482-1489. [CrossRef]

53. Hatfield, R.D.; Fukushima, R.S. Can lignin be accurately measured? Crop Sci. 2005, 45, 832-839. [CrossRef]

54. Ghosh, S.; Henry, M.P.; Christopher, R.W. Hemicellulose conversion by anaerobic digestion. Biomass 1985, 6, 257-269. [CrossRef]

55. Leschine, S. Cellulose degradation in anaerobic environments. Annu. Rev. Microbiol. 1995, 49, $399-426$. [CrossRef] [PubMed]

56. Pareek, S.; Kim, S.; Matsui, S.; Shimizu, Y. Hydrolysis of (ligno)cellulosic materials under sulphidogenic and methanogenic conditions. Water Sci. Technol. 1998, 38, 193-200. [CrossRef]

57. Palmowski, L.M.; Müller, J.A. Influence of the size reduction of organic waste on their anaerobic digestion. Water Sci. Technol. 2000, 41, 155-162. [CrossRef] [PubMed]

58. Fukushima, R.S.; Hatfield, R.D. Comparison of the Acetyl Bromide Spectrophotometric Method with Other Analytical Lignin Methods for Determining Lignin Concentration in Forage Samples. J. Agric. Food Chem. 2004, 52, 3713-3720. [CrossRef]

59. Hatfield, R.D.; Jung, H.G.; Ralph, J.; Buxton, D.R.; Weimer, P.J. A comparison of the insoluble residues produced by the Klasson lignin and acid detergent lignin procedures. J. Sci. Food Agric. 2006, 65, 51-58. [CrossRef]

60. Stenberg, B.; Jensen, L.S.; Nordkvist, E.; Breland, T.A.; Pedersen, A.; Guomundsson, J.; Bruun, S.; Salo, T.; Palmason, F.; Henriksen, T.M.; et al. Near infrared reflectance spectroscopy for quantification of crop residue, green manure and catch crop $\mathrm{C}$ and $\mathrm{N}$ fractions governing decomposition dynamics in soil. J. Near Infrared Spectrosc. 2004, 12, 331-346. [CrossRef] 